\title{
Hawaiian Volcanoes
}

During 1954

By GORDON A. MACDONALD and JERRY P. EATON

CONTRIBUTIONSTO GENERAL GEOLOGY

GEOLOGICAL SURVEY BULLETIN 1061-B

$A$ report of the Hawaiian

Volcano Observatory

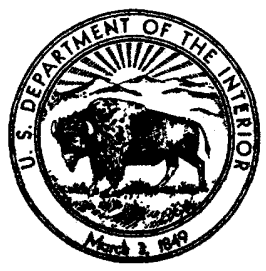


UNITED STATES DEPARTMENT OF THE INTERIOR

FRED A. SEATON, Secretary

\section{GEOLOGICAL SURVEY}

Thomas B. Nolan, Director Washington 25, D. C. - Price 60 cents (paper cover) 


\section{CONTENTS}

\begin{tabular}{|c|c|}
\hline & Page \\
\hline Abstract ... & 17 \\
\hline Introduction $\ldots \ldots \ldots \ldots \ldots \ldots \ldots$ & \\
\hline 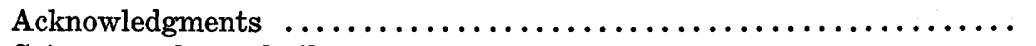 & 18 \\
\hline Seismographs and tiltmeters $\ldots \ldots \ldots \ldots \ldots \ldots \ldots \ldots \ldots \ldots \ldots$ & 18 \\
\hline 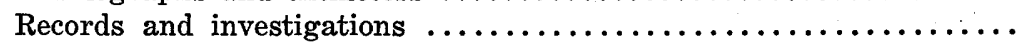 & 25 \\
\hline 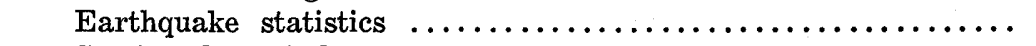 & 25 \\
\hline 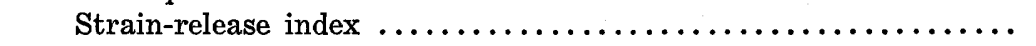 & 32 \\
\hline Tilting of the ground $\ldots \ldots \ldots \ldots \ldots \ldots \ldots \ldots \ldots \ldots \ldots \ldots$ & 34 \\
\hline Crack measurements $\ldots \ldots \ldots \ldots \ldots \ldots \ldots \ldots \ldots \ldots \ldots$ & 38 \\
\hline Geomagnetic measurements $\ldots \ldots \ldots \ldots \ldots \ldots \ldots \ldots \ldots$ & 40 \\
\hline Temperature measurements $\ldots \ldots \ldots \ldots \ldots \ldots \ldots \ldots \ldots$ & 40 \\
\hline cords $\ldots \ldots \ldots \ldots \ldots \ldots \ldots \ldots \ldots \ldots \ldots \ldots \ldots \ldots \ldots \ldots \ldots \ldots$ & 41 \\
\hline History of volcanic conditions and earthquakes $\ldots \ldots \ldots \ldots \ldots \ldots$ & 42 \\
\hline deposition and alteration on the floor of Kilauea caldera & 49 \\
\hline The east Puna earthquakes of March $30,1954 \ldots \ldots \ldots \ldots \ldots \ldots$ & 52 \\
\hline uption of Kilauea volcano $\ldots \ldots \ldots \ldots \ldots \ldots \ldots \ldots$ & 55 \\
\hline ative of the eruption $\ldots \ldots \ldots \ldots \ldots \ldots \ldots \ldots \ldots \ldots \ldots$ & 56 \\
\hline 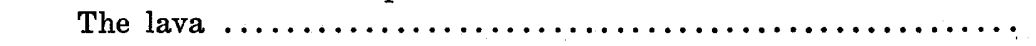 & 62 \\
\hline 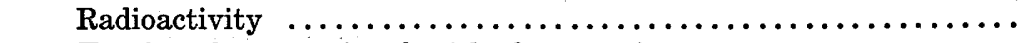 & 64 \\
\hline Earthquakes associated with the eruption $\ldots \ldots \ldots \ldots \ldots \ldots$ & 65 \\
\hline 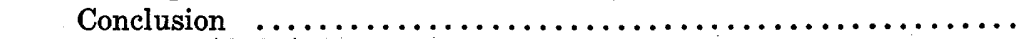 & 66 \\
\hline Publications of the Hawaiian Volcano Observatory ............ & 69 \\
\hline 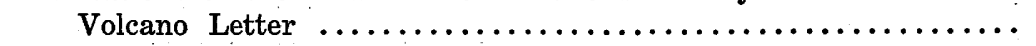 & 69 \\
\hline 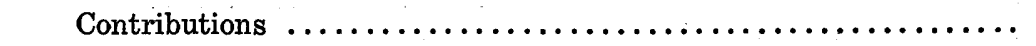 & 69 \\
\hline 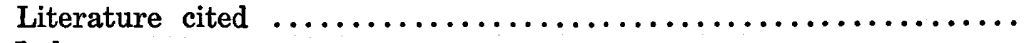 & 69 \\
\hline 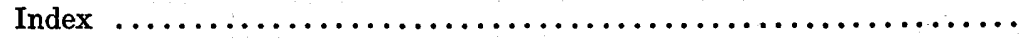 & 71 \\
\hline
\end{tabular}

\section{ILLUSTRATIONS}

Plate 1. Map of Kilauea caldera showing location of eruptive fissures and lava flow of the 1954 eruption, and some older flows outside Halemaumau ............ In pocket

2. A, Lava fountains along the fissure northeast of Halemaumau and lava flow spreading from them. $B$ Southwest fountain in Halemaumau ......... Facing

3. $A$, Northeast fountain in Halemaumau. $B$ Chain of lava fountains along the eruptive fissure northeast

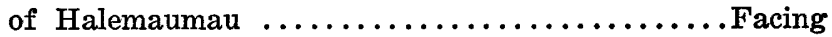

FIGURE 2. Map of the island of Hawaii, showing the location of the Hawaiian Volcano Observatory, seismograph stations, earthquake isoseismals, and localities mentioned in the text $\ldots \ldots \ldots \ldots \ldots \ldots \ldots \ldots \ldots \ldots \ldots$ 
Figure 3. Map of Kilauea caldera and its environs, showing the location of the Hawaiian Volcano Observatory and seismograph, magnetometer, and crack-measuring

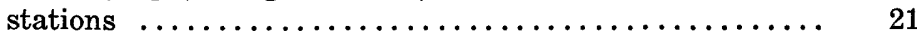

4. Radio adapter for recording time signals .......... 23

5. Radio time-signal marking pen for mechanical recorder... 24

6. Time signals recorded on seismograms $\ldots \ldots \ldots \ldots \ldots \ldots 25$

7. Graph showing strain-release index ............. 34

8. Graph showing tilting of the ground surface at the Whitney Laboratory of Seismology ............. 36

9. Graph showing tilting of the ground surface at the Uwekahuna station ..................... 37

10. Map of Kilauea caldera showing areas of pneumatolytic deposition and alteration $\ldots \ldots \ldots \ldots \ldots \ldots \ldots \ldots$

11. Map of Kilauea caldexa showing the depressions of 1823 and 1840 and the talus ridge of $1846 \ldots \ldots \ldots \ldots . \quad 52$

12. Map of the 1954 lava flow on the caldera floor north-

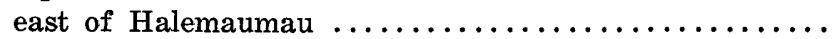

\section{TABLES}

TABLE 1. Seismographs and tiltmeters operated by the Hawaiian Volcano Observatory during $1954 \ldots \ldots \ldots \ldots \ldots \ldots$.

2. Number of earthquakes recorded per week, and weekly

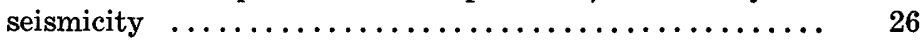

3. Local earthquakes larger than tremors $\ldots \ldots \ldots \ldots \ldots . . \ldots 27$

4. Distant earthquakes recorded $\ldots \ldots \ldots \ldots \ldots \ldots \ldots \ldots . \ldots . \ldots 1$

5. Ground tilting at seismograph stations on the rim of Kilauea caldera ........................ 38

6. Width of cracks at Kilauea .................. 39

7. Difference in vertical intensity of geomagnetism (in gammas) at stations on Mauna Loa and Kilauea, compared to that at station $0 \ldots \ldots \ldots \ldots \ldots \ldots \ldots$

8. Rainfall during $1954 \ldots \ldots \ldots \ldots \ldots \ldots \ldots \ldots \ldots \ldots . \ldots 2$

9. Chemical composition of the 1954 lava at Kilauea ....... 64 


\title{
CONTRIBUTIONS TO GENERAL GEOLOGY
}

\author{
HAWAIIAN VOLCANOES DURING 1954
}

\author{
By Gordon A. Macdonald and JerRy P. Eaton
}

\begin{abstract}
Through the early months of 1954 Kilauea volcano was uneasy. Many small earthquakes came from sources beneath the caldera and along the adjacent part of the east rift zone. On March 30 two strong earthquakes originated in eastern Puna, between Pahoa and Kalapana, probably on the system of normal faults a few miles south of the east rift zone of Kilauea, at $19^{\circ} 21^{\prime} \mathrm{N}$., $155^{\circ} \mathrm{W}$. They were followed by numerous aftershocks during the next few weeks.

From the first of April, when the Pahoa seismograph was installed, throughout the rest of the year, frequent small earthquakes from the east rift zone south and southeast of Pahoa were recorded. Tilting of the ground surface at the rim of Kilauea caldera indicated a gradual tumescence of the volcano, presumably caused by an increase of magmatic pressure beneath the caldera area.

At $4^{\mathrm{h}} 30^{\mathrm{m}}$ on May 31 an eruption began in Halemaumau crater, and less than an hour later activity spread to the adjacent floor of the caldera. During the first few hours of the eruption 15 million cubic yards of new lava poured into Halemaumau from fountains on the floor of the crater and from a spectacular cascade on the wall. At the same time a rapid flow of pahoehoe covered 139 acres of the caldera floor northeast of Halemaumau. By $7^{\mathrm{h}} 30^{\mathrm{m}}$ activity had decreased greatly, and during the late morning the pool of new lava in Halemaumau began to shrink, partly because of cooling and loss of gas, but partly also because of drainage back into the feeding conduits. Eruptive activity northeast of Halemaumau ended on the afternoon of May 31, but weak activity in Halemaumau itself continued until June 3.

The eruption caused no apparent reduction in magmatic pressure beneath Kilauea volcano, and throughout the rest of the year the pressure slowly continued to increase. Seismic activity in the caldera area and along the east rift zone also continued, and at the end of the year Kilauea was markedly uneasy. Mauna Loa remained quiet throughout the year.

The seismometric program of the Hawaiian Volcano Observatory was increased by the addition of three new stations. Tilt, temperature, and magnetic measurements continued as during previous years.
\end{abstract}

\section{INTRODUCTION}

This report continues the systematic account of conditions at Hawaiian volcanoes begun in earlier reports of this series (Finch 
and Macdonald, 1951, 1953; Macdonald and Wentworth, 1954; Macdonald, 1955; Macdonald and Eaton, 1955).

The year 1954 began with Hawaiian volcanoes quiet. The last eruption of Kilauea had ended on November 10, 1952, and the last eruption of Mauna Loa on June 23, 1950. However, Kilauea showed definite signs of uneasiness that continued during the early months of 1954 and culminated in a brief eruption in the caldera on May 31. Strong eruptive activity lasted only a few hours, and even weak activity ended on June 3. Since the end of the 1952 eruption there had been a gradual increase of pressure beneath Kilauea caldera, indicated by a slow accumulation of northward tilting at the northeast edge of the caldera. The 1954 eruption brought no marked relaxation of the pressure, and following the eruption it continued to increase slightly throughout the rest of the year. Seismic restlessness also continued throughout the fall and winter.

The scientific program of the Hawaiian Volcano Observatory continued essentially the same as during 1953. The seismometric program was considerably expanded by the addition of several new stations. Magnetometric work continued to be carried out by C. K. Wentworth.

\section{ACKNOWLEDGMENTS}

The staff of the Hawaiian Volcano Observatory wishes to express its thanks to the persons on the islands of Hawaii and Maui who have reported the occurrence of earthquakes during the year. These persons include Mr. and Mrs. Robert Baldwin, Eugene Barton, Edward W. Broadbent, Mrs. R. J. H. Farrar, George Ginn, Miss Amy Greenwell, Mrs. Alfred E. Hansen, Miss Beth Hartig, Allan P. Johnston, Mrs. D. W. Larsen, Mrs. J. H. Midkiff, Troy Osborn, Mrs. W. J. Silver, Miss Nancy R. Wallace, and Harold R. Warner.

The staff of Hawaii National Park has continued to be most cooperative and helpful throughout the year. Special thanks are due Eugene Barton, assistant superintendent of the Haleakala section of the park, and members of his staff for operating the Haleakala seismograph station.

\section{SEISMOGRAPHS AND TILTMETERS}

During 1954 new seismograph stations were put into operation at Pahoa, Naalehu, and Kamuela, on the island of Hawaii. These stations are equipped with Loucks-Omori seismographs, recording mechanically on smoked paper. The recorder speed is 60 millimeters per minute. The static magnification is 200 , and the free 
period of the pendulums is 3 seconds. The Pahoa seismograph station began operation on April 1, under the care of Kongo Kimura. It is located on the grounds of the Pahoa High and Elementary School. The Naalehu seismograph station, on the grounds of the Naalehu High and Elementary School, started operation on September 3, the attendant being Alfred H. Kahakua. The Kamuela seismograph station, on the grounds of the Waimea Elementary and Intermediate School, began operation on June 9, with John C. Mills as attendant. We wish to thank the Department of Public Instruction of the Territory of Hawaii and the Hawaii County School System for cooperation in permitting the stations to be located on school grounds.

In August 1954, a new seismograph vault was built near the southeast edge of Kilauea caldera. At the end of the year, however, the vault was still being aged and no instrument had been installed in it.

Table 1 lists the location and characteristics of the seismographs and tiltmeters operated by the Hawaiian Volcano Observatory during 1954. Figures 2 and 3 show the location of the stations.

The need for more accurate time control on seismographs of the Hawaiian Volcano Observatory has been apparent for several years. Work on a device for putting an accurate radio time signal on the seismograms was begun early in 1954, and a satisfactory device completed by summer. For earthquake work the precision in timing currently sought is one-tenth of a second. To attain this precision an accurate time base must be provided on the seismogram. The usual procedure at modern seismograph stations is to maintain a station clock, capable of running at a very uniform rate, which is equipped with contacts for marking minutes and hours on the seismogram. Time indicated by this clock is then checked periodically against the accurate radio time signals broadcast by the National Bureau of Standards stations WWV or WWVH; by one of the U. S. Naval Radio stations NSS, NPG, NPM, or NBA; or by similar institutions abroad.

Granted that a reliable station clock is available, the accuracy of the seismogram time base is limited by the accuracy of the radio time signal and the accuracy of the comparison of clock and radio time. Of the American stations, WWV, WWVH, and NSS broadcast time signals which are accurate at least to a few hundredths of a second. Signals broadcast by NPM and NPG appear to be accurate to within about one-tenth of a second. Thus, any of these stations provides time precise enough for the needs of earthquake seismology. 


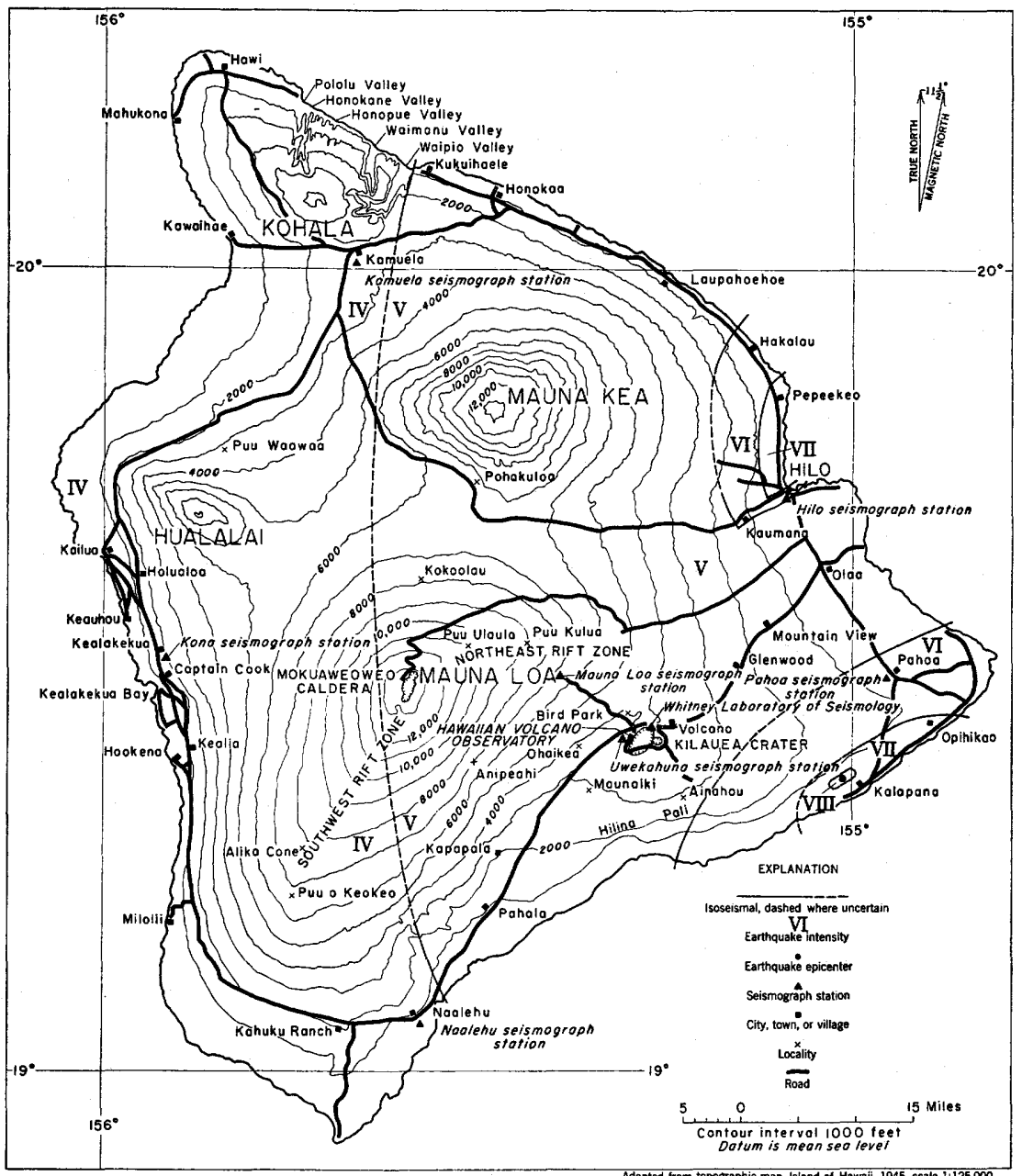

Adapted from toposgaphic map, Island of Hawail, 1945 , scale 1:125,000,
Division of Hydrography, Teritory of Hawail, and U. S. Geological Surve

FIGURE 2.-Map of the island of Hawaii, showing the location of the Hawaiian Volcano Observatory, seismograph stations operated by the observatory, the epicenter and isoseismal lines of the strong earthquake at $8^{\mathrm{h}} 42^{\mathrm{m}}$ on March 30 , and localities mentioned in the text. Intensity of the earthquake (in the modified Mercalli scale) in the different zones is indicated by the roman numerals.

The most satisfactory method for comparing radio and clock time is to record the radio time signal directly on the seismogram, permitting a clock correction to be measured with at least as great a precision as that attainable in measuring individual seismic events on the seismogram. Special receivers built to close a relay in the seismograph timing circuit in response to the make-break continuous wave signals sent out by the Naval radio stations are usually employed for this purpose. 


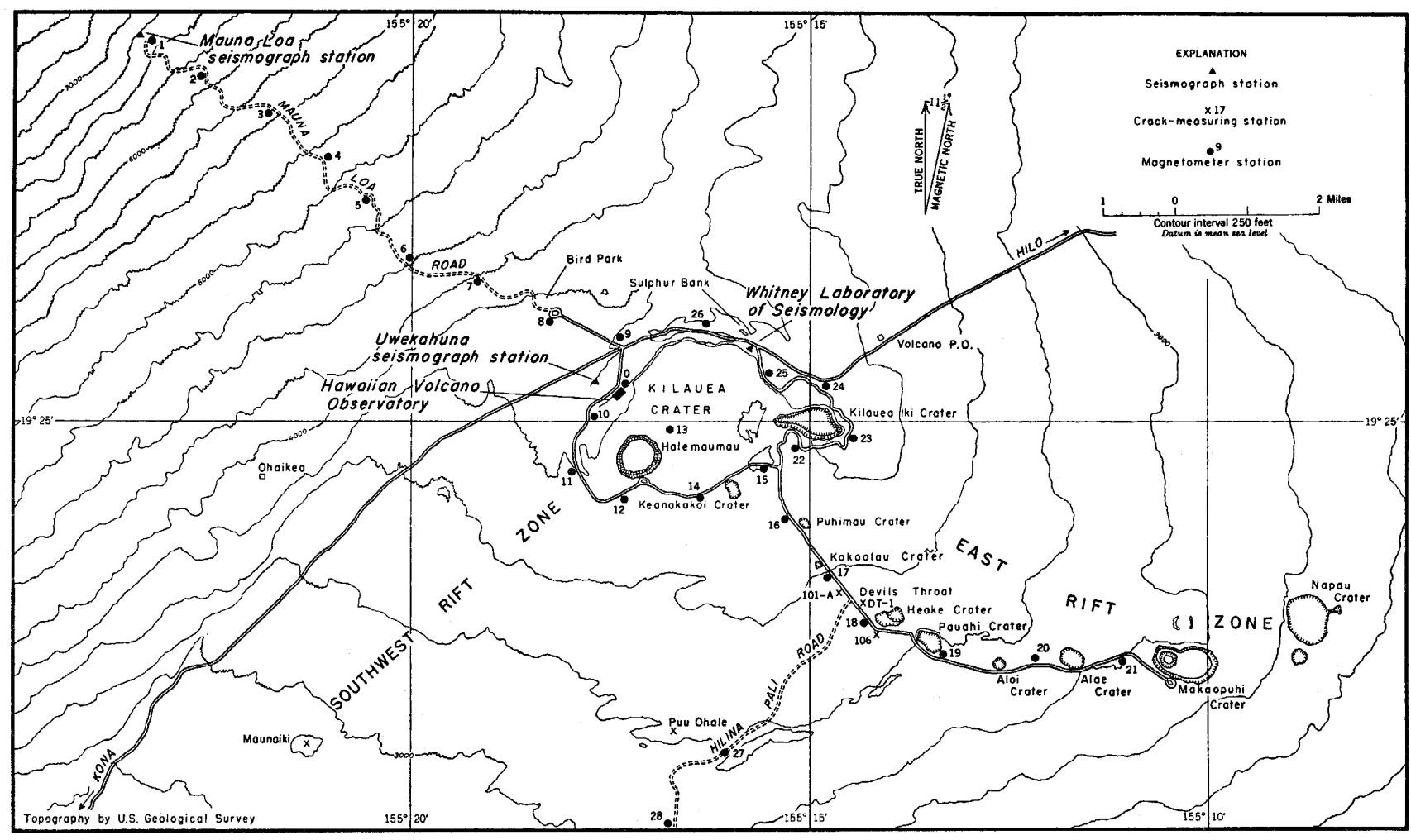

要

Figure 3.-Map of Kilauea caldera and its environs, showing the location of the Hawaiian Volcano Observatory and seismograph, magnetometer, and crack-measuring stations on the east rift zone of Kilauea volcano. 
TABLE 1.-Seismographs and tiltmeters operated by the Hawaiian Volcano Observatory during 1954

\begin{tabular}{|c|c|c|c|c|c|c|}
\hline Station & $\begin{array}{c}\text { Latitude } \\
\text { (north) }\end{array}$ & $\begin{array}{l}\text { Longitude } \\
\text { (west) }\end{array}$ & Instrument & $\begin{array}{l}\text { Period of } \\
\text { pendulum } \\
\text { (seconds) }\end{array}$ & $\begin{array}{l}\text { Magnification } \\
\text { (approximațe) }\end{array}$ & $\begin{array}{l}\text { Sensitivity } \\
\text { to tilt } \\
\text { (seconds of } \\
\text { arc per mm) }\end{array}$ \\
\hline $\begin{array}{l}\text { Whitney Laboratory of } \\
\text { Seismology (northeastern } \\
\text { rim of Kilauea caldera.) } \\
\text { Do. }\end{array}$ & $\begin{array}{l}19^{\circ} 25^{\prime} 53^{\prime \prime} \\
19^{\circ} 25^{\prime} 53^{\prime \prime}\end{array}$ & $\begin{array}{l}155^{\circ} 15^{\prime} 40^{\prime \prime} \\
155^{\circ} 15^{\prime} 40^{\prime \prime}\end{array}$ & $\begin{array}{l}\text { Bosch-Omori } \\
\text { seismograph } \\
\text { and tiltmeter. } \\
\text { Water-tube }\end{array}$ & 7.7 & 115 & 0.12 \\
\hline $\begin{array}{l}\text { Uwekahuna }(1,000 \text { fe et } \\
\text { west of western rim of } \\
\text { Kilauea caldera). }\end{array}$ & $19^{\circ} 25^{\prime} 26^{\prime \prime}$ & $155^{\circ} 17^{\prime} 36^{\prime \prime}$ & $\begin{array}{l}\text { tiltmeter. } \\
\text { Sprengnether } \\
\text { vertical } \\
\text { seismograph. }\end{array}$ & .5 & 1,750 & None \\
\hline Do & $19^{\circ} 25^{\prime} 26^{\prime \prime}$ & $155^{\circ} 17^{\prime} 36^{\prime \prime}$ & $\begin{array}{l}\text { Jaggar } \\
\text { vertical } \\
\text { seismo raph. }\end{array}$ & .4 & 250 & None \\
\hline Do $\ldots \ldots$ & $19^{\circ} 25^{\prime} 26^{\prime \prime}$ & $155^{\circ} 17^{\prime} 36^{\prime \prime}$ & $\begin{array}{l}\text { North-south } \\
\text { and East-west } \\
\text { horizontal } \\
\text { pendulum } \\
\text { tiltmeters. }\end{array}$ & 20.0 & 7 & .32 \\
\hline $\begin{array}{l}\text { Hawaiian Volcano Obser- } \\
\text { vatory (western rim of } \\
\text { Kilauea caldera). }\end{array}$ & $19^{\circ} 25^{\prime} 21^{\prime \prime}$ & $155^{\circ} 17^{\prime} 23^{\prime \prime}$ & $\begin{array}{l}\text { Imamura } \\
\text { seismograph. }\end{array}$ & 3.0 & 15 & $\ldots$ \\
\hline $\begin{array}{l}\text { Mauna Loa (altitude } 6,600 \\
\text { feet, on eastern slope of } \\
\text { Mauna Loa). }\end{array}$ & $19^{\circ} 29^{\prime} 32^{\prime \prime}$ & $155^{\circ} 23^{\prime} 29^{\prime \prime}$ & $\begin{array}{l}\text { Loucks-Omori } \\
\text { seismograph. }\end{array}$ & 3.0 & 200 & .46 \\
\hline $\begin{array}{l}\text { Hilo (St. Joseph's School). } \\
\text { Pahoa (Pahoa School). } \\
\text { Naalehu (Naalehu School). }\end{array}$ & $\begin{array}{l}19^{\circ} 43^{\prime} 11^{\prime \prime} \\
19^{\circ} 23^{\prime} 33^{\prime \prime} \\
19^{\circ} 03^{\prime} 48^{\prime \prime}\end{array}$ & $\begin{array}{l}155^{\circ} 05^{\prime} 20^{\prime \prime} \\
154^{\circ} 56^{\prime} 47^{\prime \prime} \\
155^{\circ} 35^{\prime} 10^{\prime \prime}\end{array}$ & - & $\begin{array}{l}3.0 \\
3.0 \\
3.0\end{array}$ & $\begin{array}{l}175 \\
200 \\
200\end{array}$ & $\begin{array}{l}.48 \\
.46 \\
46\end{array}$ \\
\hline $\begin{array}{l}\text { Kona (Konawaena School, } \\
\text { Kealakekua). }\end{array}$ & $19^{\circ} 30^{\prime} 47^{\prime \prime}$ & $155^{\circ} 55^{\prime} 07^{\prime \prime}$ & $\begin{array}{l}\text { Hawaiian-type } \\
\text { seismograph. }\end{array}$ & $\begin{array}{l}0.0 \\
7.3\end{array}$ & 115 & .13 \\
\hline $\begin{array}{l}\text { Kamuela (Waimea School, } \\
\text { Kamuela). }\end{array}$ & $20^{\circ} 01^{\prime} 2 \sigma^{\prime \prime}$ & $155^{\circ} 40^{\prime} 18^{\prime \prime}$ & $\begin{array}{l}\text { Loucks-Omori } \\
\text { seismorraph. }\end{array}$ & 3.0 & 200 & .46 \\
\hline $\begin{array}{l}\text { Southeast tilt cellar (floor } \\
\text { of Kilauea caldera south- } \\
\text { east of Halemaumau). }\end{array}$ & $19^{\circ} 24^{\prime} 20^{\prime \prime}$ & $155^{\circ} 16^{\prime} 59^{\prime \prime}$ & $\begin{array}{l}\text { Normal } \\
\text { pendulum } \\
\text { tiltmeter. }\end{array}$ & 3.0 & 100 & 1.3 \\
\hline $\begin{array}{l}\text { West tilt cellar (floor of } \\
\text { Kilauea caldera west of } \\
\text { Halemaumau). }\end{array}$ & $19^{\circ} 24^{\prime} 32^{\prime \prime}$ & $155^{\circ} 17^{\prime} 33^{\prime \prime}$ & - - - ndo..... & 3.0 & 100 & 1.3 \\
\hline $\begin{array}{l}\text { Haleakala (Island of } \\
\text { Maui). }\end{array}$ & $20^{\circ} 45^{\prime} 57^{\prime \prime}$ & $156^{\circ} 14^{\prime} 58^{\prime \prime}$ & $\begin{array}{l}\text { Loucks-Omori } \\
\text { seismograph. }\end{array}$ & 3.0 & 200 & .46 \\
\hline
\end{tabular}

At the Hawaiian Volcano Observatory the need arose to adapt a small commercial communications receiver (Hallicrafters S-38C) to the task of closing a relay in response either to the NPM continuous wave signal broadcast from the island of Oahu, or to the WWVH modulated signal from Maui. A diagram of the simple and inexpensive solution to this problem is given in figure 4 . The audio frequency emf appearing across the speaker transformer primary, $T$, is rectified in a voltage-doubling circuit employing two germanium diodes, $D$. The output of this system is applied to the coil of a plate circuit relay, Rel. With the circuit components' used the relay closes on about 10 volts, whereas a good, strong signal develops up to 60 volts across the relay. Since this recording device requires no operating power supply, the relay, two diodes, four condensers, and one resistor required in its construction are simply mounted on a wooden block 1 by 4 by 10 inches. The device is attached to the radio circuit by means of a phone plug and jack so that it need not interfere with the other use of the receiver. 


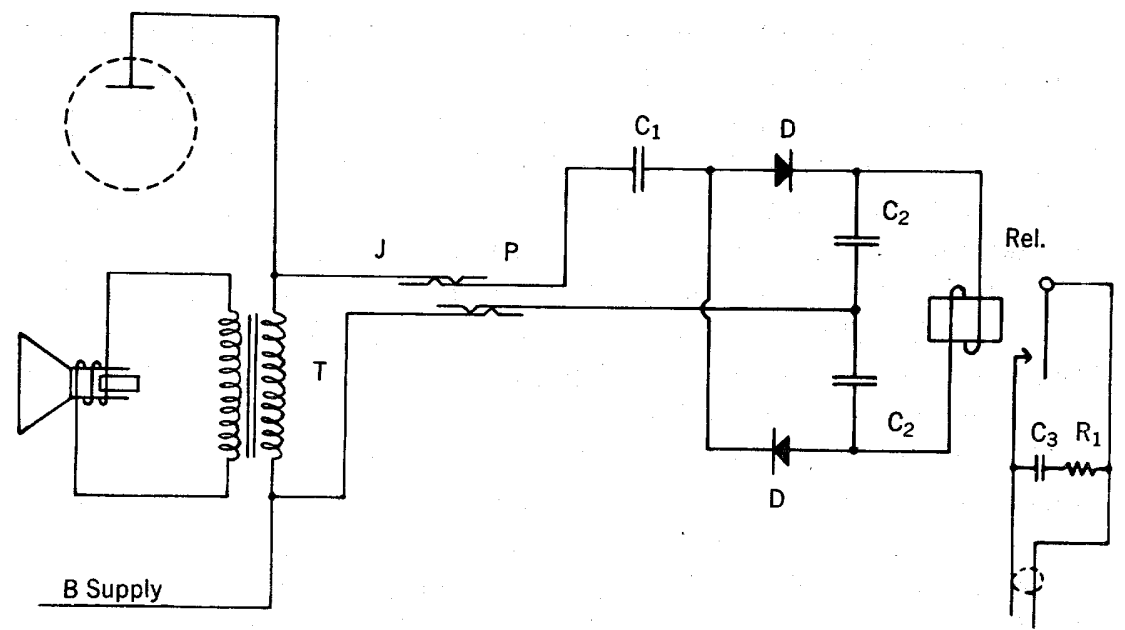

FToURe 4.-Radio adapter for recording time signals. $T$, speaker transformer; $J$, phone jack; $P$, phone plug; $C_{1}, 2 \mu \mathrm{F}$ capacitor; $C_{2}, 1 \mu \mathrm{F}$ capacitor; $C_{3}, 0.25 \mu \mathrm{F}$ capacitor $D$, germanium diode (G.E. 1N91 or 1N34A); Rel., plate circuit relay (Potter-Brumfield LS-5, $5000 \Omega$ coil); $R_{1}, 20$ to $50 \Omega 1$ watt carbon resistor. The $1 \mu \mathrm{F}$ and $2 \mu \mathrm{F}$ capacitors preferably should be pyranol, but electrolytic capacitors are satisfactory if polarization is maintained.

Signals broadcast on any frequency which can be tuned by the receiver can be used provided the structure of the signal is suitable for recording. At the Hawaiian Volcano Observatory the signal from WWVH has proved to be most useful. Beginning on the hour, WWV broadcasts a 600 cycles per second (cps) audiofrequency and a 1 cps modulation consisting of $51,000 \mathrm{cps}$ pulses at the beginning of each second. This $1 \mathrm{cps}$ modulation, or "tick," as it sounds on the receiver, is omitted on the 59th second of each minute. During the 4 th minute of the hour the audiofrequency is omitted; code, voice announcements, and the 1 cps modulation are broadcast during this minute. At exactly $\mathbf{5}$ minutes after the hour a $440 \mathrm{cps}$ audiofrequency comes on. This frequency and the $1 \mathrm{cps}$ modulation continue for 4 minutes, then the $440 \mathrm{cps}$ tone goes off and another minute of code, voice announcements, and "ticks" follows. The foregoing 10-minute cycle is repeated 6 times per hour and continues day and night. Except for minor periodic interruptions, the WWVH signal is the same as that of WWV. The adapter described above closes the relay during periods of audiofrequency, code, voice announcements, and, with moderate signal strength, at each of the 1 cps "ticks." The timing event most clearly recordable is the return of the audiofrequency after the 1 minute of audiofrequency silence.

If photographic recording is employed the adapter relay contacts can be placed in parallel with the clock relay contacts to permit the radio time signal to be recorded by the minute-mark 
deflector system. If mechanical recording is used and the writing points are lifted to record time marks, it is convenient to record the radio time signal by a separate writing point which is deflected horizontally by the radio signal and is lifted from the paper by the clock signal. In practice the clock correction is obtained once a day when the record is changed. The operator drops the timing needle onto the drum and tunes the radio to record the signal. After the signal has been recorded he lifts the timing pen to avoid interference with the seismograph pens during the registration of earthquakes.

Figure 5 is a diagram of the time marker used with the mechanically recording Loucks-Omori seismographs built at the observatory. The pen is lifted by the regular pen-lift magnet used to record clock time. In addition the pen is carried on a flexible arm which is deflected horizontally by another electromagnet controlled by the radio.

One difficulty in the use of this time-marking system originated in the "feedback" through the receiver of the static generated

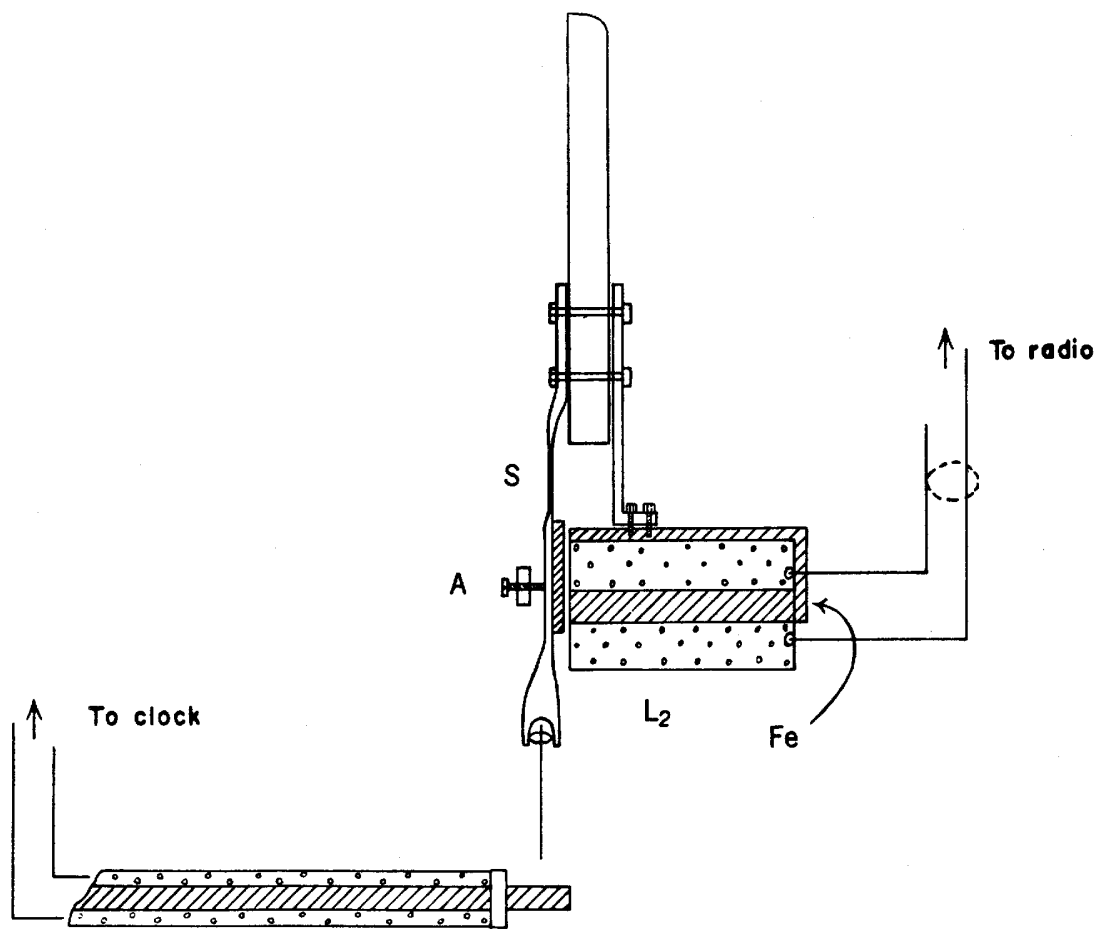

$L_{1}$

Frgure 5.-Radio time-signal marking pen for mechanical recorder. $L_{1}$, pen-lift magnet; $L_{2}$, pen-deflector magnet; $F e$, iron core and armature; $A$, amplitude adjustment screw; $S$, Gexible pen arm. 
at the relay contacts. This difficulty was overcome by employing a half-wave doublet antenna with a twin-line lead-in to the receiver; by placing a simple capacity-resistance filter across the relay contacts and near each heavy inductance in the time-signal marking circuit; and by using shielded conductors in this circuit.

Figure 6 illustrates WWVH time signals recorded on the photographic record of the Sprengnether and on the smoked-paper record of the Loucks-Omori seismographs.

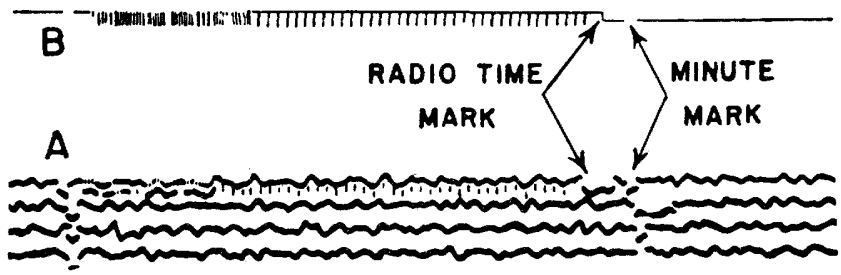

FGGURE 6.-WWVH time signals recorded on an optical $(A)$ and mechanical $(B)$ seismograph.

\section{RECORDS AND INVESTIGATIONS}

EARTHQUAKE STATISTICS

The Bosch-Omori seismograph at the Whitney Laboratory of Seismology recorded 2,579 earthquakes during 1954. Several hundred more were recorded on the more sensitive Sprengnether vertical seismograph at the Ukekahuna station. The number of quakes recorded per week on the Bosch-Omori seismograph ranged from 3 to 1,011, and the weekly seismicity ranged from 1.25 to 268.0 , as shown in table 2 .

Local seismicity is an arbitrary value. Each local earthquake is assigned a seismicity value according to its strength. These values are totaled to give the weekly local seismicity. Continuous volcanic tremor is ignored in the calculation. The strength assigned to the earthquake depends on the double amplitude of the maximum oscillation it causes on the Bosch-Omori seismograph, as follows:

Intensity of earthquake

Tremor

Very feeble $\ldots \ldots \ldots \ldots \ldots \ldots \ldots \ldots \ldots$

Feeble

Slight

Moderate

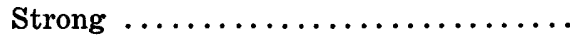

$\begin{array}{cc}\begin{array}{c}\text { Double amplitude of motion } \\ \text { on Bosch-Omori seismo- } \\ \text { oraph (millimeters) }\end{array} & \begin{array}{c}\text { Seismicity } \\ \text { value }\end{array} \\ <0.5 & .25 \\ 0.5-4 & .5 \\ 4-11 & 1.0 \\ 11-25 & 2.0 \\ 25-60 & 3.0 \\ >60 & 4.0\end{array}$

It is noteworthy that throughout the year, and particularly after the first of May, both the total number of earthquakes per 
week and the weekly seismicity value generally were in excess of the norms for the 20-year period, 1934-53 (Macdonald and Eaton, 1955, p. 142). The excess reflects a marked uneasiness of Kilauea volcano, not relieved by the brief eruption of May 31 to June 3. It may be noted that the uneasiness continued into 1955 and culminated in the big eruption on the east rift zone from February 28 to May 26, 1955.

TABLE 2.-Number of earthquakes recorded per week, and weekly seismicity at the Hawaiian Volcano Observatory during 1954

[Based on the Bosch-Omori seismograph in the Whitney Laboratory of Seismology]

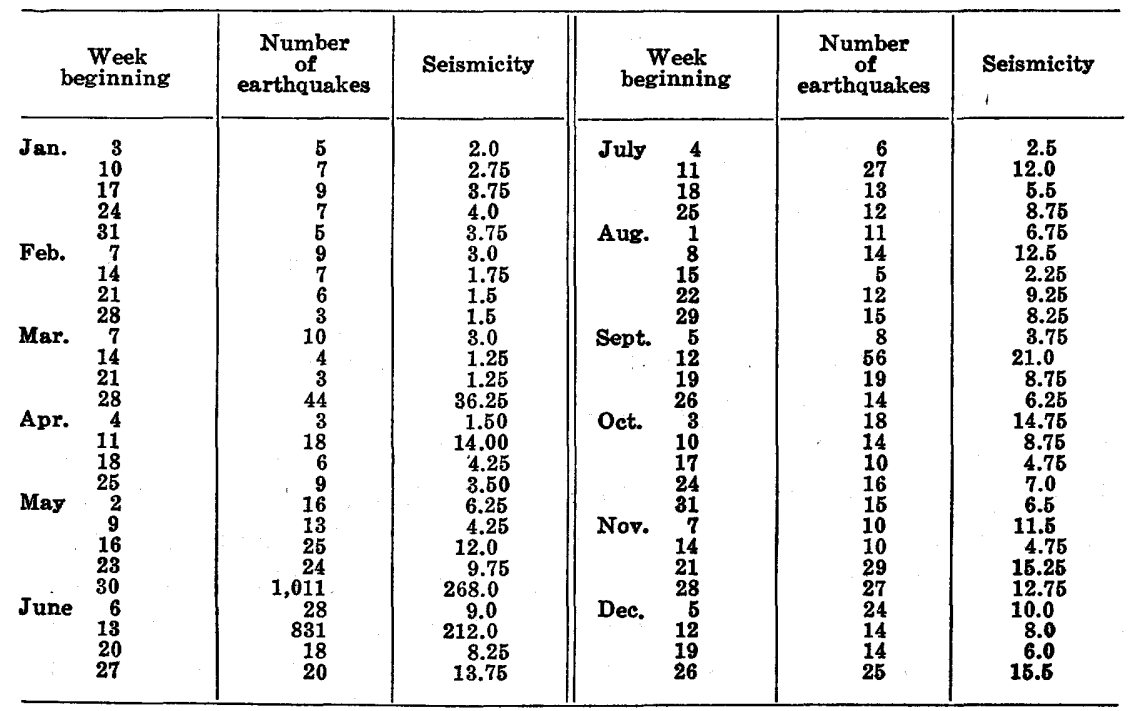

Table 3 lists all the earthquakes larger than very feeble recorded by Hawaiian Volcano Observatory seismographs during 1954, together with the date and time of the quake, the intensity of the quake at the Whitney Laboratory, the approximate position of the epicenter, and other information. If the intensity was greater at one of the other stations than it was at the Whitney Laboratory, the name of the station and the intensity rating there are given in the column headed "remarks." Except where otherwise indicated, the times given are arrival times at the Uwekahuna station, and are stated in Hawaiian standard time, which is 10 hours behind Greenwich civil time. The number given in the first column of the table is the serial number of the earthquake for the year 1954. The sequence of numbers is incomplete because, although each earthquake is assigned a serial number, the earthquakes recorded at the observatory which are smaller than feeble are omitted from the table. 
TABLE 3.-Local earthquakes larger than very feeble recorded by Hawaiian Volcano Observatory seismographs during 1954

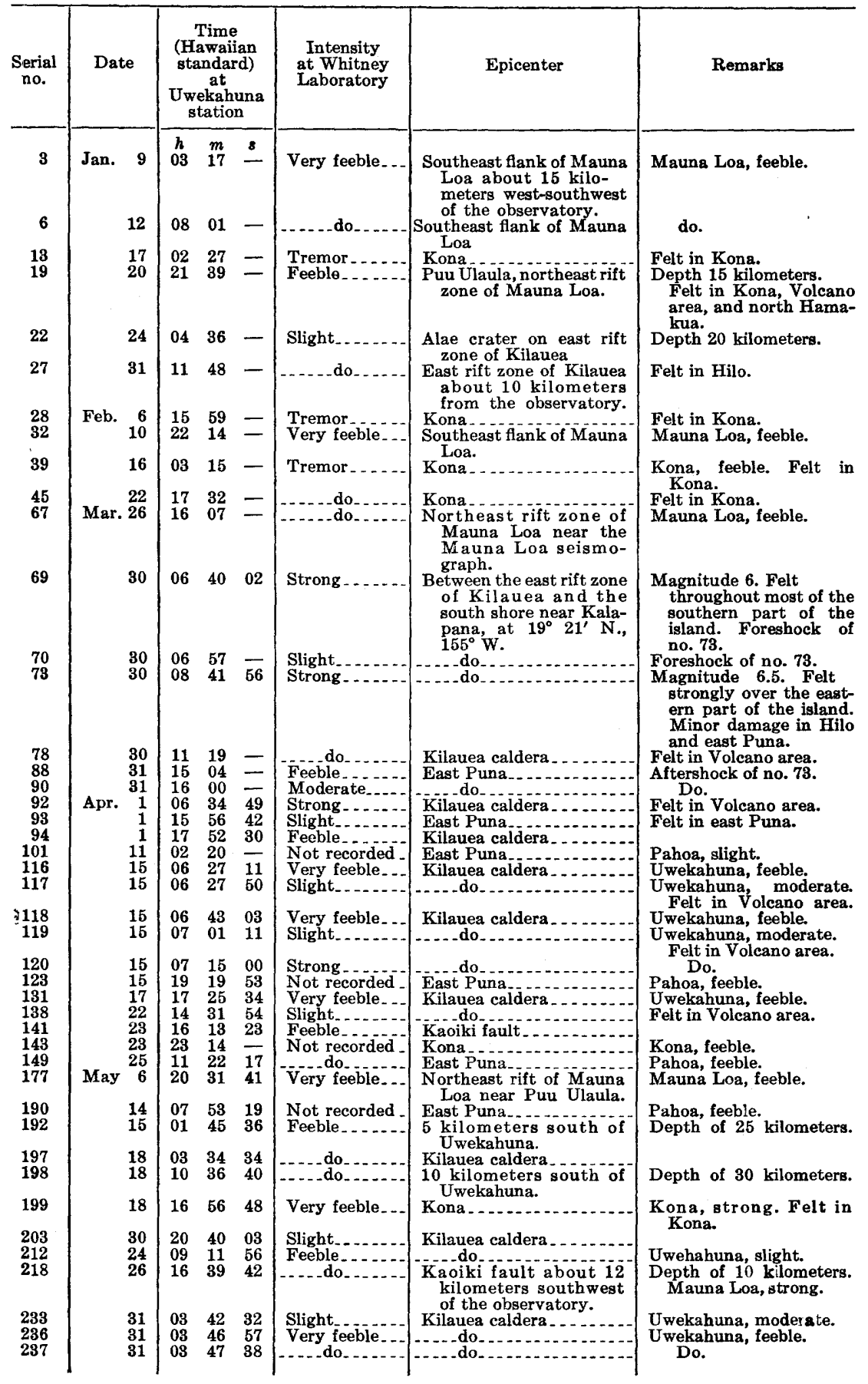


TABLE 3.-Local earthquakes larger than very feeble recorded by Hawaiian Volcano Observatory seismographs during 1954 - Continued

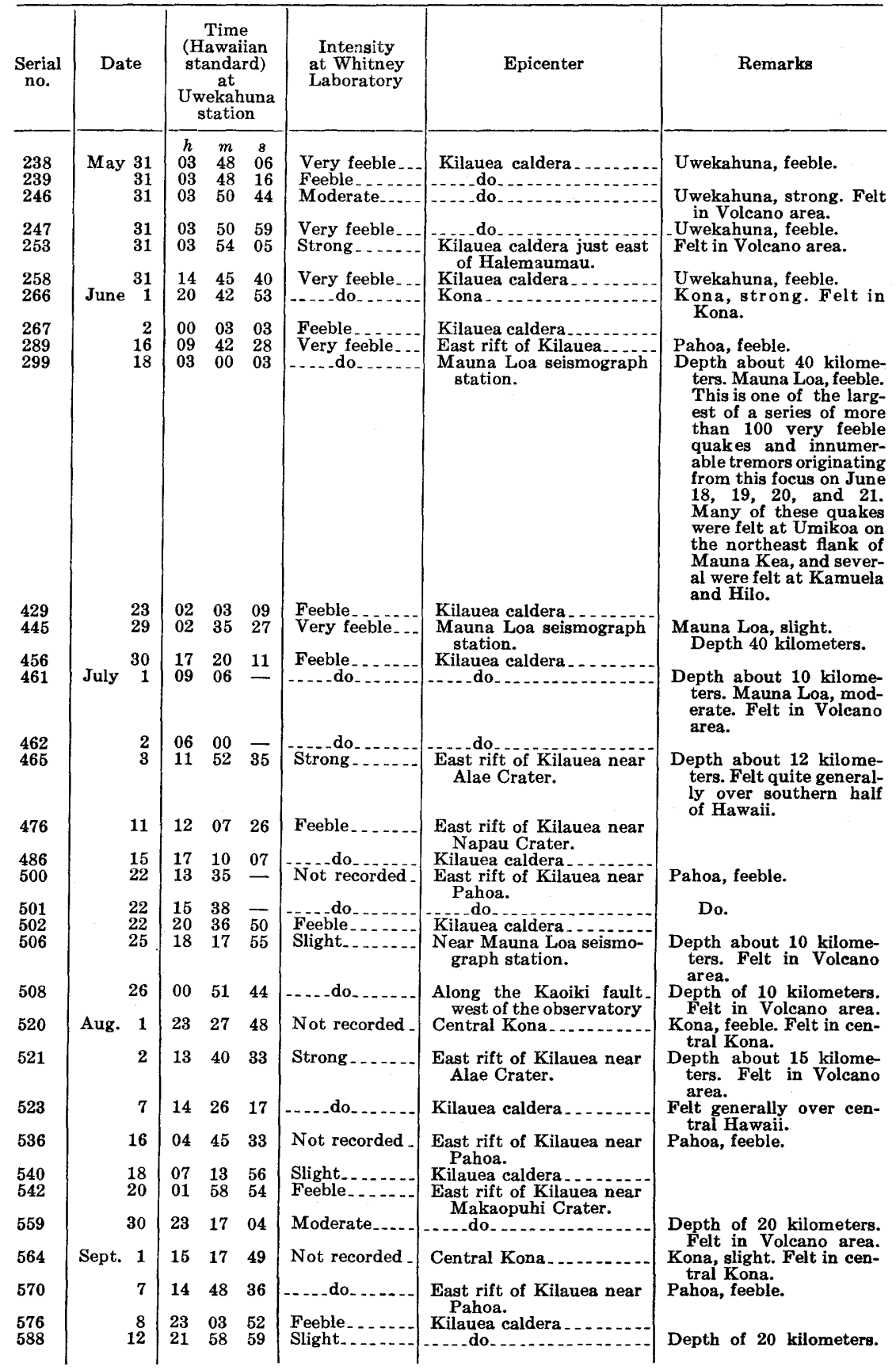


TABLE 3.-Local earthquakes larger than very feeble recorded by Hawaiian Volcano Observatory seismographs during 1954 - Continued

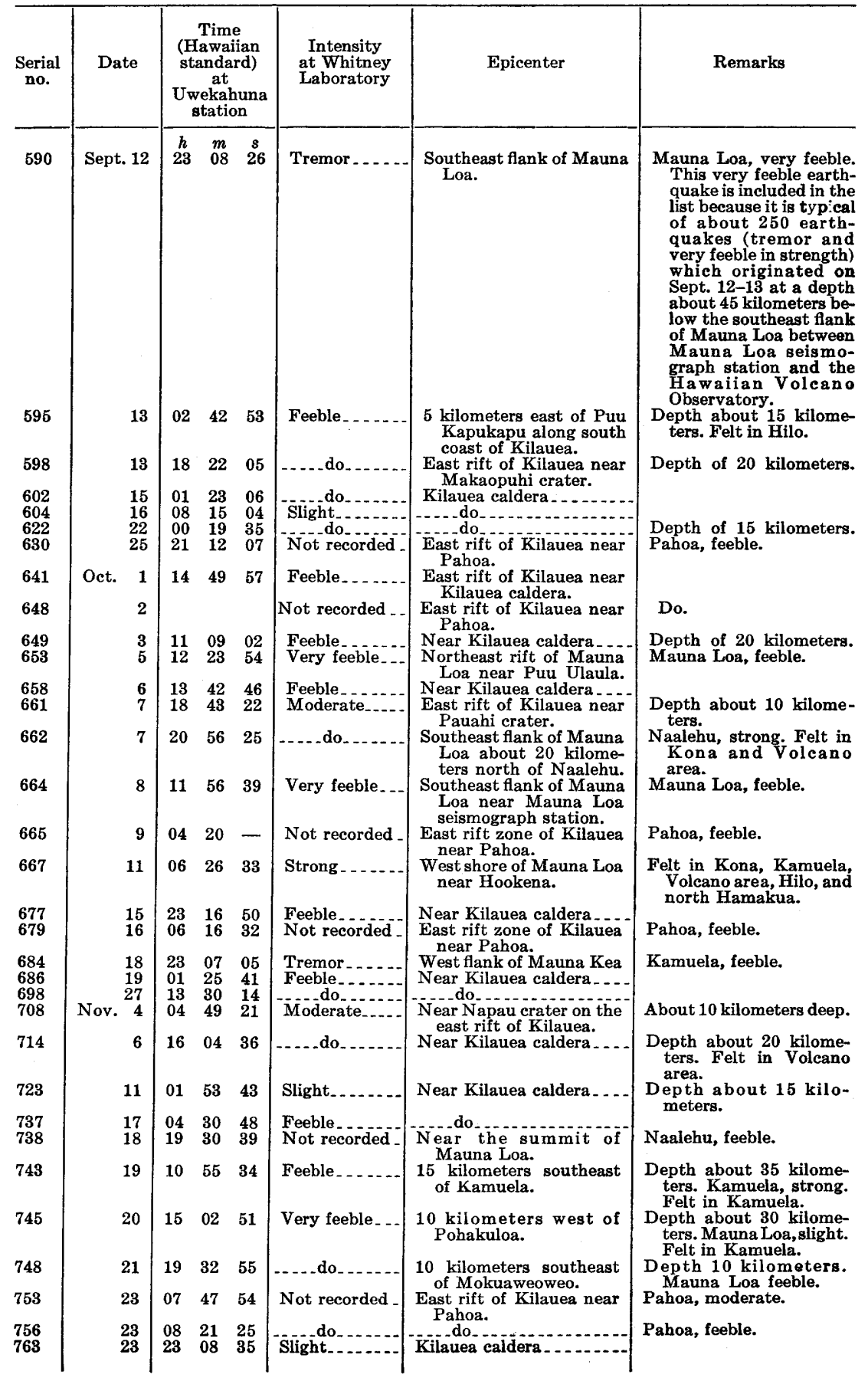


TABLE 3.-Local earthquakes larger than very feeble recorded by Hawaiian Volcano Observatory seismographs during 1954 - Continued

\begin{tabular}{|c|c|c|c|c|c|c|c|c|}
\hline \multirow{2}{*}{$\begin{array}{c}\begin{array}{c}\text { Serial } \\
\text { no. }\end{array} \\
771\end{array}$} & \multicolumn{2}{|c|}{ Date } & \multicolumn{3}{|c|}{$\begin{array}{c}\text { Time } \\
\text { (Hawaiian } \\
\text { standard) } \\
\text { at } \\
\text { Uwekahuna } \\
\text { station }\end{array}$} & \multirow{2}{*}{$\begin{array}{c}\begin{array}{c}\text { Intensity } \\
\text { at Whitney } \\
\text { Laboratory }\end{array} \\
\text { Not recorded - }\end{array}$} & \multirow{2}{*}{$\begin{array}{c}\text { Epicenter } \\
\begin{array}{c}\text { East rift zone of Kilauea } \\
\text { near Pahoa. }\end{array}\end{array}$} & Remarks \\
\hline & Nov. & & $\begin{array}{c}h \\
02\end{array}$ & $\begin{array}{c}m \\
20\end{array}$ & $\begin{array}{l}s \\
19\end{array}$ & & & Pahoa feeble. \\
\hline $\begin{array}{l}773 \\
776\end{array}$ & & $\begin{array}{l}26 \\
26\end{array}$ & $\begin{array}{l}02 \\
05\end{array}$ & $\begin{array}{l}30 \\
50\end{array}$ & $\overline{24}$ & - & East rift zone of Kilauea & $\begin{array}{l}\text { Do. } \\
\text { Do. }\end{array}$ \\
\hline 779 & & 26 & 11 & 34 & 05 & Feeble _.... & $\begin{array}{l}\text { near Pahoa. } \\
\text { East rift zone of Kilauea }\end{array}$ & Felt in Volcano area. \\
\hline $\begin{array}{l}786 \\
789\end{array}$ & & $\begin{array}{l}26 \\
27\end{array}$ & $\begin{array}{l}15 \\
08\end{array}$ & $\begin{array}{l}37 \\
04\end{array}$ & $\begin{array}{l}59 \\
58\end{array}$ & Not recorded. & $\begin{array}{l}\text { near Kilauea caldera } \\
\text { Neart - - } \\
\text { East rift of Kilauea near }\end{array}$ & Pahoa, feeble. \\
\hline $\begin{array}{l}797 \\
811\end{array}$ & Dec. & & $\begin{array}{l}17 \\
06\end{array}$ & $\begin{array}{l}27 \\
35\end{array}$ & $\begin{array}{l}34 \\
56\end{array}$ & $\begin{array}{l}\text { Feeble } \\
\text { Not recorded. }\end{array}$ & $\begin{array}{l}\text { Panoa. } \\
\text { Near Kilauea caldera } . . . .\end{array}$ & Depth about 45 kilo- \\
\hline $\begin{array}{l}815 \\
818 \\
833\end{array}$ & & $\begin{array}{l}4 \\
4 \\
5\end{array}$ & $\begin{array}{l}08 \\
14 \\
10\end{array}$ & $\begin{array}{l}49 \\
29 \\
46\end{array}$ & $\begin{array}{l}\overline{36} \\
42\end{array}$ & $\begin{array}{l}\text { Slight } \\
\text { Feeble......... }\end{array}$ & $\begin{array}{l}\text { Hilina Pali } \\
\text { East rift of Kilauea near }\end{array}$ & $\begin{array}{l}\text { Do. } \\
\text { Felt in Hilo and Pahala. }\end{array}$ \\
\hline 837 & & 5 & 20 & 59 & 15 & Tremor . . . . . & $\begin{array}{l}\text { Napau crater. } \\
\text { Near Kilauea caldera } \ldots\end{array}$ & $\begin{array}{l}\text { Depth about 45 kilome- } \\
\text { ters. Pahoa, feeble; } \\
\text { Kona and Mauna Loa, } \\
\text { very feeble. Felt in } \\
\text { Kona and Kau. This is } \\
\text { the largest of a swarm } \\
\text { of more than } 200 \text { earth- } \\
\text { quakes originating at } \\
\text { about the same place } \\
\text { on Dec. 4-5. }\end{array}$ \\
\hline $\begin{array}{l}840 \\
841\end{array}$ & & $\begin{array}{l}6 \\
6\end{array}$ & $\begin{array}{l}08 \\
10\end{array}$ & $\begin{array}{l}55 \\
15\end{array}$ & $\underline{07}$ & Not recorded & $\begin{array}{l}\text { Offshore west of Hualalai } \\
\text { Kona }\end{array}$ & $\begin{array}{l}\text { Kona, feeble. } \\
\text { Kona, feeble. Felt in }\end{array}$ \\
\hline 848 & & 9 & 16 & 02 & 18 & ....do....... & East rift of Kilauea near & Pahoa, feeble. \\
\hline $\begin{array}{l}863 \\
866\end{array}$ & & $\begin{array}{l}14 \\
14\end{array}$ & $\begin{array}{l}11 \\
17\end{array}$ & $\begin{array}{l}01 \\
35\end{array}$ & $\begin{array}{l}04 \\
26\end{array}$ & Very feeble... & Between Mauna Loa and & $\begin{array}{l}\text { Pahoa, moderate. } \\
\text { Depth about } 15 \text { kilome- } \\
\text { ters. Kamuela feeble. }\end{array}$ \\
\hline $\begin{array}{l}867 \\
868\end{array}$ & & 14 & 22 & 25 & $\begin{array}{l}52 \\
30\end{array}$ & Moderate.... & $\begin{array}{l}\text { Kilauea caldera } \\
\text { Near Kilauea caldera }\end{array}$ & Felt in Volcano area. \\
\hline 887 & & 22 & 02 & 50 & 52 & Not recorded & $\begin{array}{l}\text { East rift of Kilauea near } \\
\text { Pahoa. }\end{array}$ & Pahoa, feeble. \\
\hline 899 & & 23 & 12 & 45 & 54 & Tremor...... & Near Kamuela & $\begin{array}{l}\text { Depth about } 25 \text { kilome- } \\
\text { ters. Kamuela moder- } \\
\text { ate. Felt at Kamuela } \\
\text { and north Kohala. } \\
\text { Pahoa, feeble. }\end{array}$ \\
\hline 904 & & 28 & 03 & 06 & 36 & Moderate_.... & Just south of Kilauea & Shallow \\
\hline $\begin{array}{l}905 \\
906 \\
907\end{array}$ & & $\begin{array}{l}28 \\
28 \\
28\end{array}$ & $\begin{array}{l}03 \\
07 \\
08\end{array}$ & $\begin{array}{l}31 \\
26 \\
49\end{array}$ & $\begin{array}{l}26 \\
22 \\
17\end{array}$ & $\begin{array}{l}\text { Slight } \\
\text { Feeble }\end{array}$ & $\begin{array}{l}\text { Kaoiki fault near Hailf- } \\
\text { way House. }\end{array}$ & $\begin{array}{l}\text { Do. } \\
\text { Do. } \\
\text { Depth of } 15 \text { kilometers. } \\
\text { Felt in Volcano area. }\end{array}$ \\
\hline
\end{tabular}

Table 4 lists the earthquakes of distant origin recorded during the year on seismographs of the Hawaiian Volcano Observatory (latitude $19^{\circ} 24.5^{\prime} \mathrm{N}$. longitude $155^{\circ} 17.7^{\prime} \mathrm{W}$.). The epicentral locations, depths of focus, and magnitudes are taken from the notices of Preliminary Determinations of Epicenters published by the U. S. Coast and Geodetic Survey. Beginnings of phases are given in Hawaiian standard time. 
TABLE 4.-Distant earthquakes recorded by seismographs of the Hawaiian Volcano Observatory during 1954

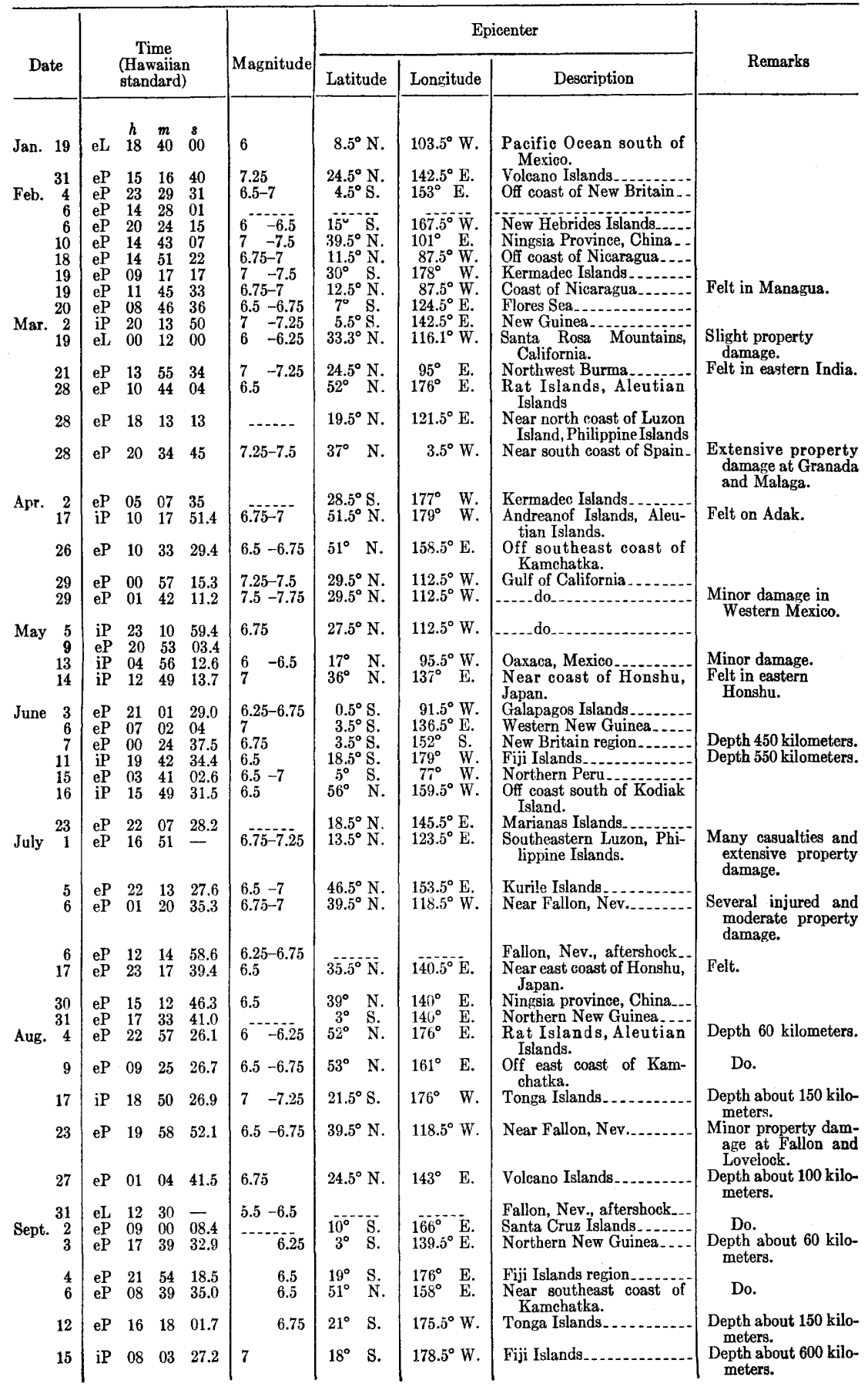


TABLE 4.-Distant earthquakes recorded by seismographs of the Hawaiian Volcano Observatory during 1954-Continued

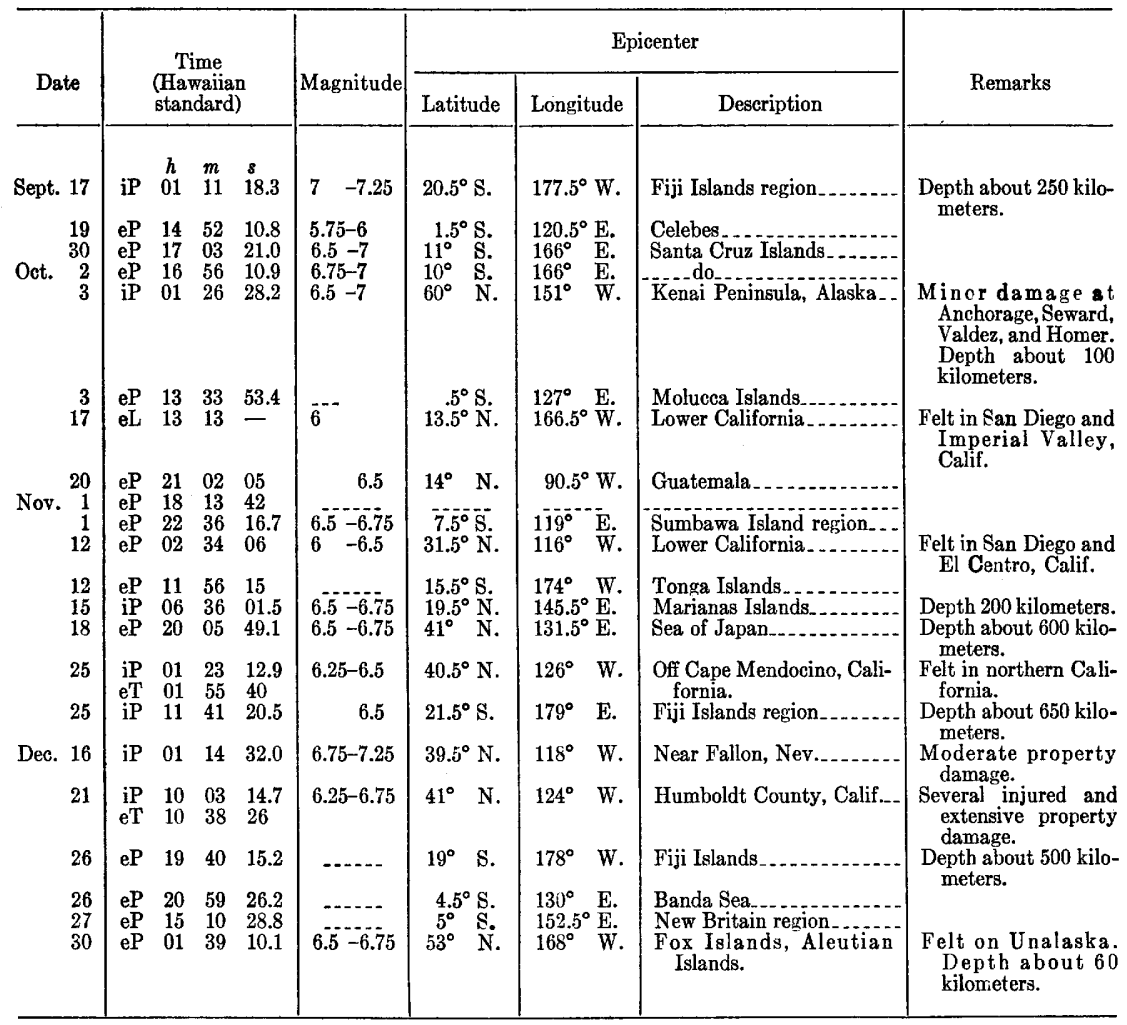

\section{STRAIN-RELEASE INDEX}

The scale of seismicity that has been in use for many years at the Hawaiian Volcano Observatory is at the best only an approximate indication of the relative amounts of energy released by earthquakes during given periods. It has been apparent for some time that a more precise and quantitative approach is desirable. An attempt at this is the strain-release index.

Benioff (1951) has pointed out, under certain simplifying assumptions, that if a uniformly strained body be released suddenly from its strained state by faulting, a fraction of the energy so released radiating outward as seismic waves, the amount of strain released is proportional to the square root of the energy released. If magnitudes of the earthquakes considered are available, this energy can be obtained from the Gutenberg-Richter (1942) magnitude-energy formula. To date, determinations of magnitudes of local Hawaiian earthquakes has been impeded by 
proximity of recording stations to the epicenters and by variable focal depths. Pending a solution of these problems an approach somewhat different from Benioff's will be followed.

Supposing that we are dealing with regular sinusoidal body waves in a homogeneous medium, at any distance from the focus the duration of the preliminary tremor multiplied by the amplitude of the largest wave is constant and is proportional to the square root of the energy in the earthquake. For earthquakes of moderate range in size recorded at small epicentral distances, the above relationship permits us to calculate a quantity proportional to the strain release without knowing the earthquake's magnitude.

Dealing only with local earthquakes, we can adopt one instrument as standard and avoid the reduction of recorded amplitudes to earth amplitudes. Thus, the product $(S-P) \times A$-where $S-P$ and $A$ are, respectively, the duration of the preliminary tremor and the maximum amplitude of a given earthquake recorded on the Sprengnether vertical seismograph at Uwekahuna-is a measure of the strain release or the faulting or fracturing which generated the earthquake.

Because of the great difference between the energy released by a large earthquake and that released by a small one, $(S-P) \times A$ shows a great variation from large to small earthquakes. Since the many small earthquakes which precede eruptions of Hawaiian volcanoes and which appear to be a significant premonitory symptom of eruption are dwarfed relative to the infrequent, much larger earthquakes occurring at times remote from eruptions, an additional weighting device is employed. The strainrelease index of a given earthquake is defined as:

$$
S-R \text { index }=\sqrt{(S-P) \mathrm{A}}
$$

where $S-P$ and $A$ are as defined above.

To obtain geologic units small enough that its rocks may be considered to be acted upon by a single system of forces it is necessary to divide the volcanoes into units, guided insofar as possible by the known geology. For the present purpose the Kilauean unit is taken as the volcano Kilauea minus the eastern half of its long east rift zone. Strain-release indices for earthquakes larger than tremors originating in this unit were computed for 1953-54. When records from the standard instrument, the Sprengnether vertical seismograph at Uwekahuna, were not available, records from other instruments located around Kilauea caldera were used. In such cases, empirically determined amplitude correction factors were applied to obtain strain-release indices corresponding to those from the Sprengnether seismograph. 
In figure 7 are plotted weekly strain-release indices (the sum of the strain-release indices of earthquakes occurring during a given week), and cumulative strain-release indices, for 1953-54.

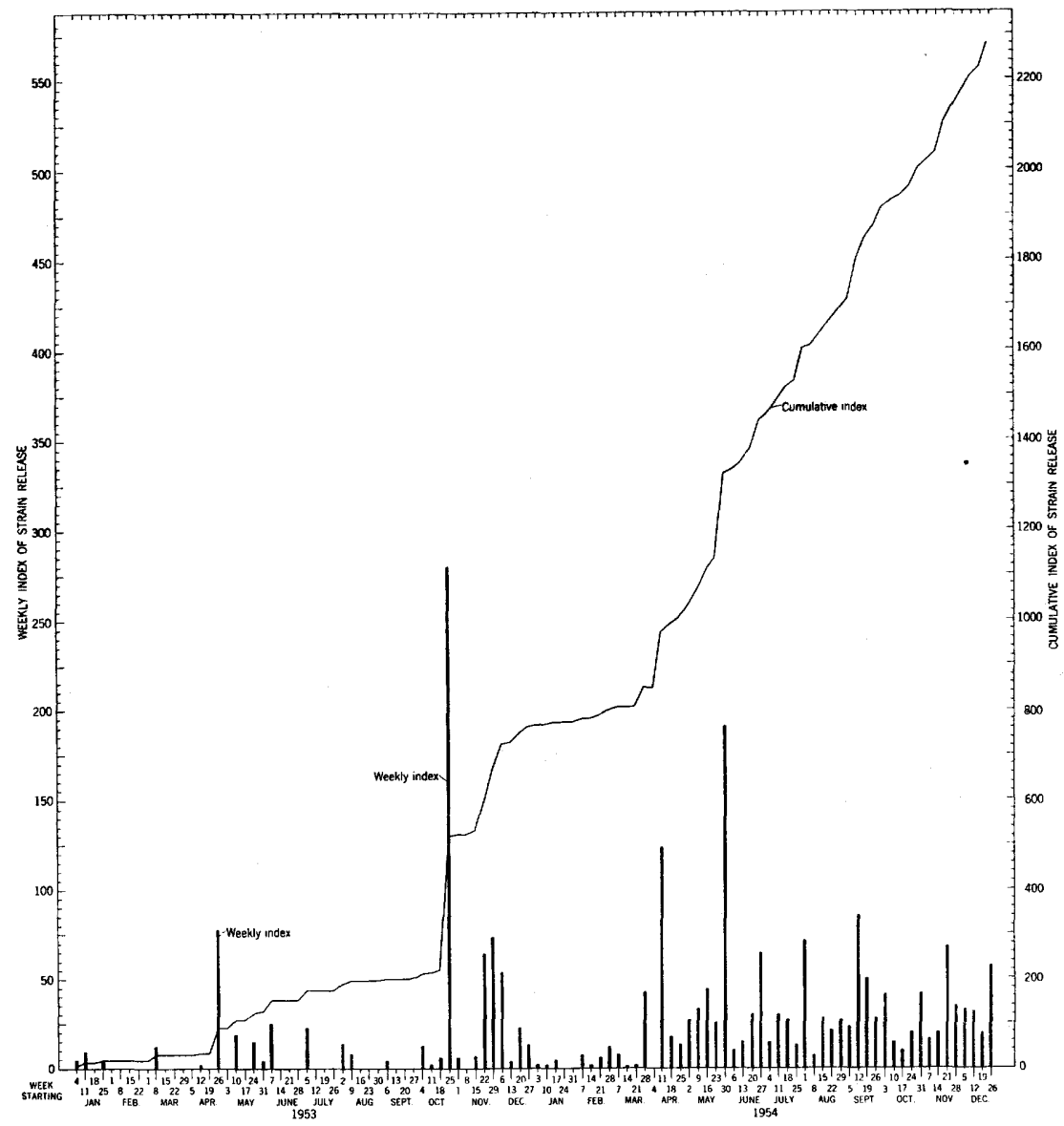

FIGURE 7.-Graph showing weekly strain-release index (vertical bars) and cumulative strainrelease index (continuous curve) for the Kilauea caldera region during 1953-54. An increase in steepness of rise of the cumulative curve represents an increase in the rate of strain release through earthquakes. Earthquakes on the Kilauea rift zone east of a point 13 miles east of the caldera and on the Hilina and Kaoiki fault zones are not included.

The slope, not the height, of the latter curve is significant: it is a measure of the rate of strain release in the volcano.

\section{TILTING OF THE GROUND}

Tilting of the ground surface is measured at the Whitney Laboratory of Seismology, on the northeastern rim of Kilauea 
caldera, by means of the Bosch-Omori sesmograph; at the Uwekahuna station near the western rim of the caldera, by means of a pair of horizontal pendulum tiltmeters; at all other seismograph stations except the Kona station, by means of Loucks-Omori seismographs ; and at two stations on the floor of Kilauea caldera just southeast and west of Halemaumau, by means of normal pendulums (table 1). Measurements obtained at the Whitney and Uwekahuna stations are listed in table 5.

Figure 8 shows the tilting of the ground measured at the northeastern rim of Kilauea caldera during the year. Also shown are the approximate average annual tilt curves determined for years in which there was no eruptive activity of either Kilauea or Mauna Loa. Any marked variation of the curves of actual measured tilt from those of the average annual tilt probably is the result of variations in volcanic conditions, presumably tumescence or detumescence of the mountain in response to changes in subsurface magmatic pressure. Figure 9 shows the ground tilting measured at the Uwekahuna station near the western rim of the caldera. The record at the Uwekahuna station is not yet long enough to permit the construction of average curves.

It is immediately apparent from figure 8 that in a general way the curves representing the tilting actually measured during the year closely approximated in shape the curves of average annual tilting during years without volcanic activity. Examined in more detail, however, the curve of the north-south component of the measured tilt is seen to rise more steeply from April to mid-August than does that of the average. This represents a net northward tilting, and tumescence of the mountain, probably caused by an increase of magmatic pressure. It is noteworthy that the brief eruption in Kilauea caldera from May 31 to June 3 produced no appreciable deflection of the trend of the tilt curves. The eruption apparently did not cause any important decrease in magmatic pressures beneath Kilauea.

Since early 1952, there had been a gradual climb of both measured tilt curves, particularly that of the north-south component, above the position of the average curves (Macdonald, 1955, p. 44; Macdonald and Eaton, 1955, p. 144). The climb was interrupted briefly by the 1.952 eruption, but resumed immediately afterward and became very pronounced in the spring of 1953. By the end of 1954, the north-south curve of measured tilt showed an accumulation of approximately 24 seconds of arc of northward tilting in excess to the normal. Considered in retrospect, the inflation of the volcanic edifice indicated by this excess of northward tilting appears to have set the stage for the impending major eruption 
on the east rift that began on February 28, 1955. At the time, the significance of the accumulating northward tilting was in doubt, because it was not known whether the position of the curve of measured tilt in relation to the average curve was significant, or whether the only real significance was to be attached to the slope of the measured curve over relatively short time intervals, as

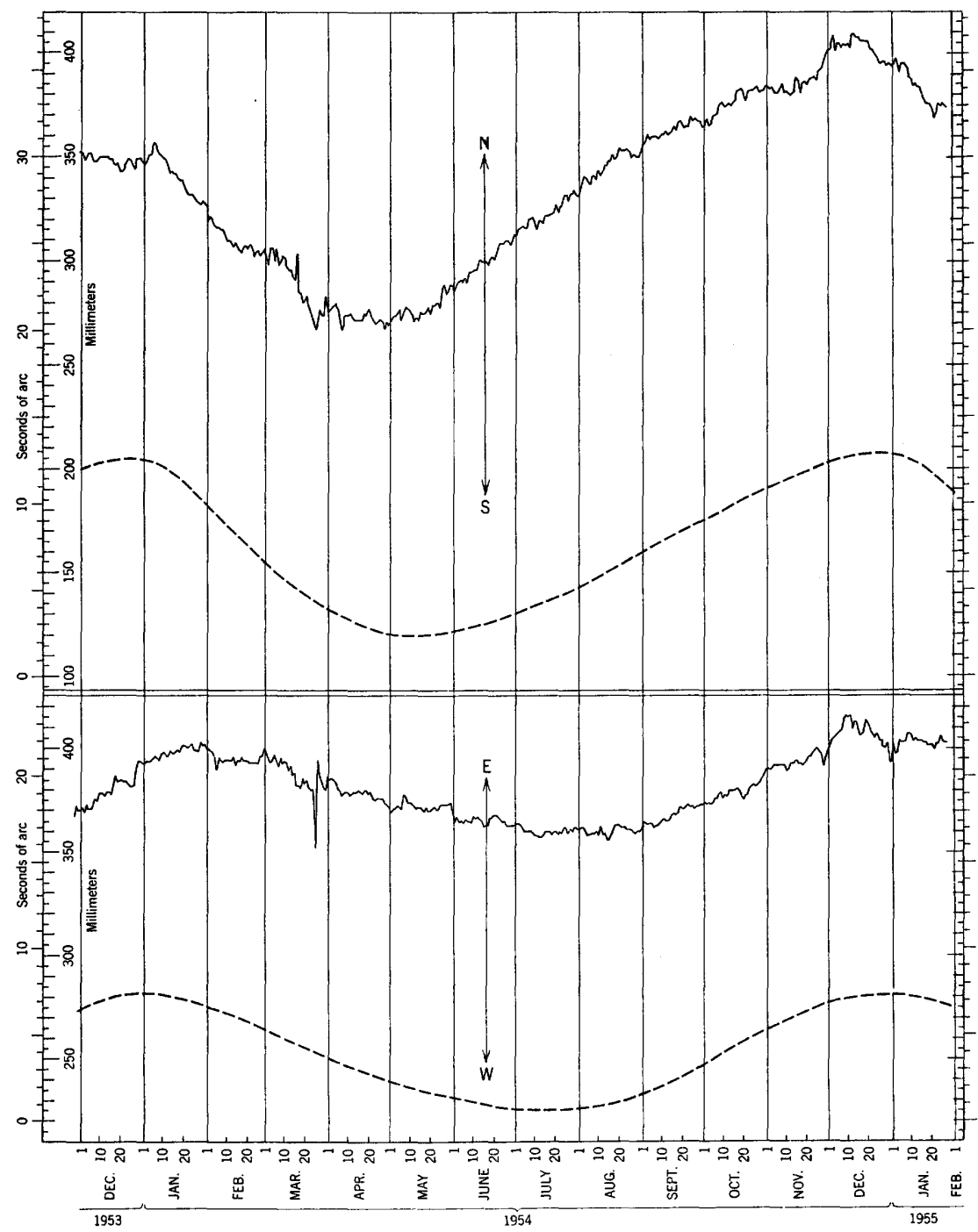

Figure 8.-Graph showing tilting of the ground surface at the Whitney Laboratory of Seismology, on the northeastern rim of Kilauea caldera, during 1954. The solid line shows the tilt as measured during the year. The dashed line is the approximate normal annual curve for years in which there is no volcanic disturbance. 


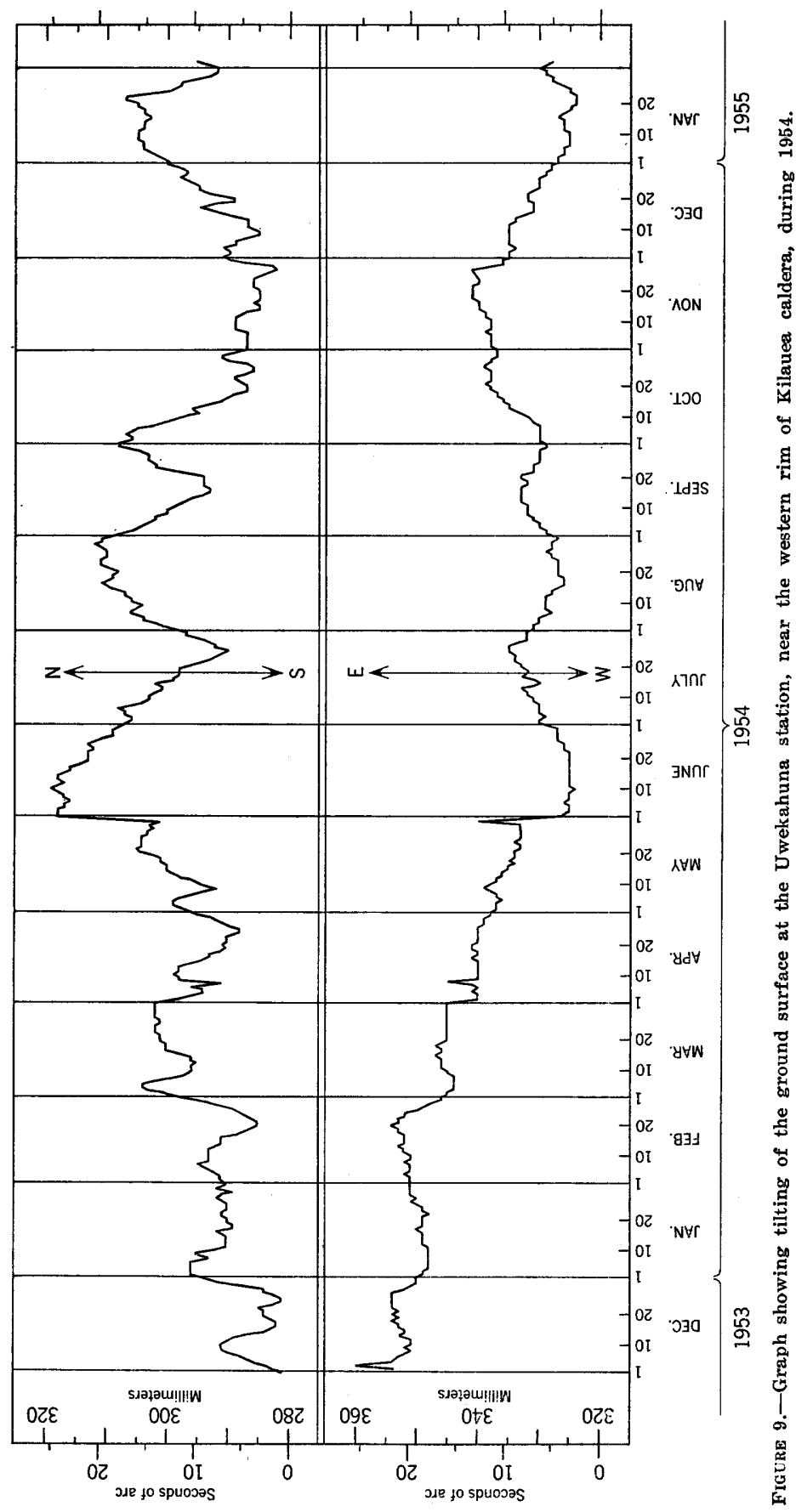


compared with the slope of the average curve. We now believe that the absolute position of the two curves is of great significance in indicating long-period tumescence and detumescence of the volcano.

TABLE 5.-Ground tilting at seismograph stations on the rim of Kilauea caldera during 1954

\begin{tabular}{|c|c|c|c|c|c|c|c|c|c|c|c|}
\hline \multirow{2}{*}{\multicolumn{2}{|c|}{$\begin{array}{l}\text { Week } \\
\text { beginning }\end{array}$}} & \multicolumn{2}{|c|}{$\begin{array}{l}\text { Whitney station } \\
\text { (northeastern rim) }\end{array}$} & \multicolumn{2}{|c|}{$\begin{array}{l}\text { Uwekahuna"station } \\
\text { (western rim) }\end{array}$} & \multirow{2}{*}{\multicolumn{2}{|c|}{$\begin{array}{c}\text { Week } \\
\text { beginning }\end{array}$}} & \multicolumn{2}{|c|}{$\begin{array}{l}\text { Whitney station } \\
\text { (northeastern rim) }\end{array}$} & \multicolumn{2}{|c|}{$\begin{array}{l}\text { Uwekahuna station } \\
\text { (western rim) }\end{array}$} \\
\hline & & $\begin{array}{l}\text { Amount } \\
\text { (sec. of } \\
\text { are) }\end{array}$ & Direction & $\begin{array}{l}\text { Amount } \\
\text { (sec. of } \\
\text { are) }\end{array}$ & Direction & & & $\begin{array}{l}\text { Amount } \\
\text { (sec. of } \\
\text { arc) }\end{array}$ & Direction & $\begin{array}{l}\text { Amount } \\
\text { (sec. of } \\
\text { arc) }\end{array}$ & Direction \\
\hline \multirow[t]{4}{*}{ Jan. } & & 0.5 & S. $14^{\circ} \mathrm{E}$. & 1.3 & S. $14^{\circ} \mathrm{W}$. & July & 4 & $\emptyset .4$ & S. $56^{\circ} \mathrm{W}$. & 1.8 & S. $31^{\circ} \mathrm{E}$. \\
\hline & 10 & 1.2 & S. $6^{\circ} \mathrm{E}$. & 1.2 & S. $34^{\circ} \mathrm{W}$. & & 11 & 1.0 & N. & 1.3 & S. \\
\hline & 17 & .1 & S. $21^{\circ} \mathrm{E}$ & .5 & N. $45^{\circ} \mathrm{W}$. & & 18 & 1.3 & N. $30^{\circ} \mathrm{E}$. & 2.7 & S. $21^{\circ} \mathrm{E}$. \\
\hline & 24 & .8 & S. $18^{\circ} \mathrm{W}$. & .6 & E. & & 25 & .4 & N. $18^{\circ} \mathrm{W}$. & 3.0 & N. $19^{\circ} \mathrm{W}$. \\
\hline \multirow{4}{*}{ Feb. } & $\begin{array}{r}31 \\
7\end{array}$ & 1.5 & $\begin{array}{l}\text { S. } 29^{\circ} \mathrm{W} \text {. } \\
\text { S. } 18^{\circ} \mathrm{W}\end{array}$ & 1.6 & ${ }_{14^{\circ}}^{\mathrm{N}} \cdot$ & Aug. & 1 & .8 & N. $18^{\circ} \mathrm{W}$. & 2.2 & N. $26^{\circ} \mathrm{W}$. \\
\hline & 14 & .20 & S. $45^{\circ} \mathrm{W}$. & $\begin{array}{l}1.0 \\
1.9\end{array}$ & S. $9^{\circ} \mathrm{E}$. & & 15 & $\begin{array}{r}1.0 \\
.9\end{array}$ & N. $56^{\circ} \mathrm{E}$. & $\begin{array}{r}1.1 \\
.3\end{array}$ & N. \\
\hline & 21 & .9 & S. $16^{\circ} \mathrm{W}$. & 4.2 & $\mathrm{~N} .33^{\circ} \mathrm{W}$. & & 22 & .4 & S. $33^{\circ} \mathrm{W}$. & .4 & N. $45^{\circ} \mathrm{E}$. \\
\hline & 28 & 1.4 & S. $45^{\circ} \mathrm{W}$. & 1.2 & N. $34^{\circ} \mathrm{W}$. & & 29 & 1.3 & N. $21^{\circ} \mathrm{E}$. & 2.9 & S. $12^{\circ} \mathrm{E}$. \\
\hline \multirow[t]{3}{*}{ Mar. } & 7 & .8 & S. $45^{\circ} \mathrm{W}$. & 1.2 & S. $34^{\circ} \mathrm{E}$. & Sept. & 5 & .4 & N. $18^{\circ} \mathrm{E}$ & 2.1 & S. $26^{\circ} \mathrm{E}$. \\
\hline & 14 & 1.1 & S. $13^{\circ} \mathrm{W}$. & 1.6 & N. $11^{\circ} \mathrm{W}$. & & 12 & 1.0 & N. $53^{\circ} \mathrm{E}$. & 1.0 & S. $18^{\circ} \mathrm{W}$. \\
\hline & $\begin{array}{l}21 \\
28\end{array}$ & 1.2 & $\mathrm{~N} . \stackrel{\mathrm{S}}{9^{\circ} \mathrm{W}}$ & .3 & $\stackrel{\text { N. }}{7^{\circ} \mathrm{W}}$ & & $\begin{array}{l}19 \\
26\end{array}$ & .2 & $\mathrm{~N} .45^{\circ} \mathrm{W}$. & 2.3 & N. $17^{\circ} \mathrm{W}$. \\
\hline \multirow[t]{4}{*}{ April } & 4 & 1.03 & S. $26^{\circ} \mathrm{W}$. & $\begin{array}{l}4.9 \\
1.32\end{array}$ & N. $14^{\circ} \mathrm{W}$. & loet. & $\begin{array}{r}40 \\
3\end{array}$ & $\begin{array}{l}.0 \\
.3\end{array}$ & N. $45^{\circ} \mathrm{E}$. & & S. $1^{\circ} \mathrm{E}$. \\
\hline & 11 & .36 & E. & 2.58 & S. $7^{\circ} \mathrm{E}$ & & 10 & .9 & N. $40^{\circ} \mathrm{E}$. & 3.0 & S. $32^{\circ} \mathrm{E}$. \\
\hline & 18 & .60 & S. $37^{\circ} \mathrm{W}$. & .32 & S. & & 17 & .1 & E. & .7 & S. $27^{\circ} \mathrm{E}$. \\
\hline & 25 & .61 & N. $11^{\circ} \mathrm{W}$. & 2.74 & N. $21^{\circ} \mathrm{W}$. & & 24 & 1.0 & N. $76^{\circ} \mathrm{E}$. & .7 & N. $27^{\circ} \mathrm{W}$. \\
\hline \multirow[t]{5}{*}{ May } & 2 & .60 & N. $37^{\circ} \mathrm{E}$. & 1.72 & S. $22^{\circ} \mathrm{E}$. & & 31 & .3 & S. $63^{\circ} \mathrm{E}$. & .6 & E. \\
\hline & 9 & .42 & S. $34^{\circ} \mathrm{W}$. & 2.58 & N. $30^{\circ} \mathrm{W}$. & Nov. & 7 & .3 & S. $63^{\circ} \mathrm{E}$. & 1.3 & S. $17^{\circ} \mathrm{E}$. \\
\hline & 16 & .61 & N. $11^{\circ} \mathrm{W}$. & 1.43 & N. $27^{\circ} \mathrm{W}$. & & 14 & .6 & N. $22^{\circ} \mathrm{E}$. & .4 & $\mathrm{~N} .45^{\circ} \mathrm{E}$ \\
\hline & 23 & 1.18 & N. $24^{\circ} \mathrm{E}$. & .96 & $\mathrm{~S}$ & & 21 & 1.2 & N. $29^{\circ} \mathrm{W}$. & 1.1 & S. $33^{\circ} \mathrm{W}$. \\
\hline & 30 & 1.03 & N. $24^{\circ} \mathrm{W}$. & 5.30 & N. $25^{\circ} \mathrm{W}$. & & 28 & 2.2 & N. $61^{\circ} \mathrm{E}$. & 2.3 & N. $34^{\circ} \mathrm{W}$. \\
\hline \multirow[t]{3}{*}{ June } & 6 & 1.08 & N. & .72 & N. $27^{\circ} \mathrm{W}$. & Dec. & 5 & .5 & N. $26^{\circ} \overline{\mathrm{E}}$. & .6 & S. \\
\hline & 13 & .24 & $\frac{\mathrm{E}}{\mathrm{n} 0^{\circ} \mathrm{W}}$ & 1.60 & S. & & 12 & .7 & S. $59^{\circ} \mathrm{E}$ & 1.4 & N. $63^{\circ} \mathrm{W}$. \\
\hline & $\begin{array}{l}20 \\
27\end{array}$ & $\begin{array}{r}1.23 \\
.72\end{array}$ & $\begin{array}{l}\text { N. } 29^{\circ} \text { W. } \\
\text { N. }\end{array}$ & $\begin{array}{l}1.43 \\
1.36\end{array}$ & $\begin{array}{l}\text { S. } 27^{\circ} \text { E. } \\
\text { SE. }\end{array}$ & & $\begin{array}{l}19 \\
26\end{array}$ & $\begin{array}{r}1.8 \\
.8\end{array}$ & $\begin{array}{l}\text { S. } 42^{\circ} \mathrm{W} . \\
\text { S. }\end{array}$ & $\begin{array}{l}2.6 \\
1.6\end{array}$ & N. $36^{\circ} \mathrm{W}$. \\
\hline
\end{tabular}

\section{CRACK MEASUREMENTS}

Measurements of crack widths were made at 15 stations on the floor of Kilauea caldera and along the east rift zone of Kilauea volcano at approximately monthly intervals throughout 1954. The locations of the crack-measuring stations on the east rift zone are shown in figure 3. (For those of the stations on the caldera floor see figure 4, Macdonald and Eaton, 1955.) The measurements are given in table 6 .

Cracks 5 and 6 , near the southeastern rim of Halemaumau crater, opened rapidly throughout the year. Early on May 13 collapse of part of the crater rim just northeast of station 5 carried away old measuring station 5A, together with a block of the rim rock 100 feet long and averaging 10 feet in width. About a week later, the end of the smaller block holding measuring station 20 also collapsed into the crater, destroying the station. The crater rim continued to collapse actively for 3 months after the end of the eruption, on June 3, producing large and rapidly growing 
TABLE 6.-Width of cracks at Kilauea during 1954, in centimeters

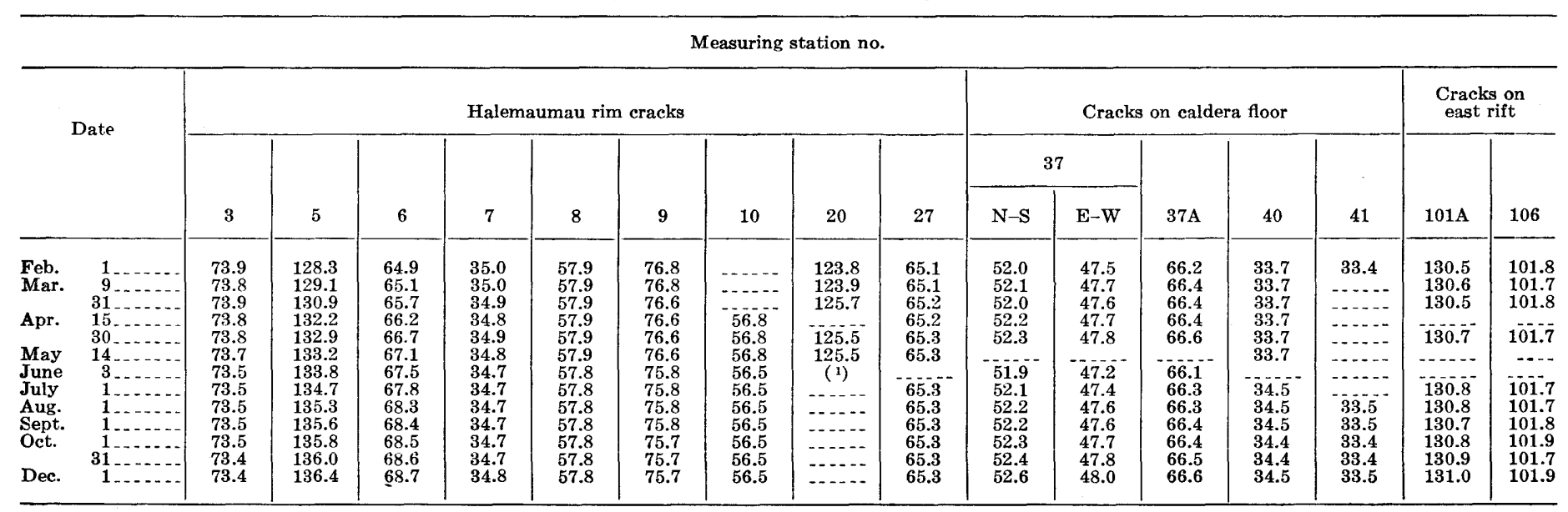

1 Measuring station destroyed; block of rim fell into crater. 
taluses on the new lava. Cracks 7, 8, 9, and 10, behind and south of the visitors' observation area on the southeastern rim, closed slightly, apparently indicating that there was no immediate danger to the observation area.

Cracks 37 and $37 \mathrm{~A}$, which apparently are related to the southwest rift zone of the volcano, opened slightly during the early months of the year as a result of the tumescence that preceded the eruption; closed briefly during and just after the eruption; and again opened from July to the end of December. The latter opening correlates with the tumescence indicated by ground tilting, leading up to the eruption of $\mathbf{1 9 5 5 .}$

\section{GEOMAGNETIC MEASUREMENTS}

Measurements of the relative intensity of the vertical component of the earth's magnetic field at stations on Kilauea volcano and adjacent parts of Mauna Loa were continued by C. K. Wentworth during 1954. The method of making the measurements is described in an earlier report (Macdonald and Wentworth, 1954, p. 163-165). The location of the stations is shown in figure 3.

Table 7 lists the readings obtained during 1954. All readings in the table are differences (in gammas) of the vertical intensity at each of the other magnetometer stations from that at station 0 , near the Hawaiian Volcano Observatory, on the same date.

The very large changes in differences exhibited by some stations have not been corroborated by independent measurements and are open to serious question. They probably are the result of poor operational procedure, or poor performance of the instrument itself. It is hoped, in the near future, to make check readings with better instruments employing more careful techniques.

\section{TEMPERATURE MEASUREMENTS}

Measurements of steam temperatures at Sulphur Bank (fig. 3) were continued at irregular intervals throughout 1954. The temperature of the steam escaping from the drilled well (Finch and Macdonald, 1951, p. 116) remained constant at $95.8^{\circ} \mathrm{C}$ from January to October, but dropped to $95.5^{\circ}$ in December. Measurement of temperatures at the natural vents near the east end of the fumarolic area was abandoned because partial collapse of the walls of the vents during March and April changed the shape of the vent openings, altering the exposure of the vent to wind and rain. A reduction of temperature from $94.4^{\circ} \mathrm{C}$ to $93.3^{\circ} \mathrm{C}$, that accompanied this change of shape of the vents, does not appear to result from any real change in temperature of the escaping 
TABLE 7.-Difference in vertical intensity of geomagnetism, in gammas, at stations on Mauna Loa and Kilauea, compared to that at station 0 during 1954

\begin{tabular}{|c|c|c|c|c|c|c|}
\hline $\begin{array}{l}\text { Station } \\
\text { no. }\end{array}$ & $\underset{22,23}{\text { March }}$ & $\underset{26}{\text { April }}$ & $\mathbf{J u n}_{\mathbf{y}}$ & $\begin{array}{c}\text { September } \\
6,7\end{array}$ & $\begin{array}{c}\text { October } \\
20,21\end{array}$ & $\begin{array}{c}\text { December } \\
20,22\end{array}$ \\
\hline $\begin{array}{l}1 \\
2 \\
3 \\
4 \\
5\end{array}$ & $\begin{array}{rr} & 845 \\
= & 101 \\
& 276 \\
& 354 \\
+\quad 18\end{array}$ & $\begin{array}{r}\quad 805 \\
=\quad 50 \\
\quad 349 \\
\quad 377 \\
+\quad 111\end{array}$ & $\begin{array}{r}795 \\
+\quad 28 \\
\mp \quad 289 \\
\quad 340 \\
+\quad 111\end{array}$ & $\begin{array}{r}764 \\
\quad 14 \\
\quad 308 \\
\quad 290 \\
+\quad 110\end{array}$ & $\begin{array}{rr} & 832 \\
= & 64 \\
-\quad 257 \\
\quad 520 \\
\quad 28\end{array}$ & 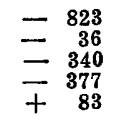 \\
\hline $\begin{array}{r}6 \\
7 \\
8 \\
9 \\
10\end{array}$ & $\begin{array}{l}-161 \\
=\quad 170 \\
=\quad 697 \\
=\quad 840 \\
=\quad 757\end{array}$ & $\begin{array}{ll}- & 124 \\
= & 124 \\
= & 644 \\
- & 842 \\
- & 685\end{array}$ & $\begin{array}{l}115 \\
=\quad 101 \\
=\quad 731 \\
=\quad 837 \\
-\quad 713\end{array}$ & $\begin{array}{r}\quad 92 \\
=\quad 230 \\
=\quad 722 \\
=\quad 856 \\
-\quad 695\end{array}$ & $\begin{array}{l}=124 \\
=\quad 142 \\
=\quad 685 \\
=\quad 874 \\
7 \quad 745\end{array}$ & $\begin{array}{r}=147 \\
=\quad 165 \\
=713 \\
=\quad 857 \\
-\quad 704\end{array}$ \\
\hline $\begin{array}{l}11 \\
12 \\
13\end{array}$ & $\begin{array}{l}192 \\
=\quad 234 \\
-\quad 514\end{array}$ & $\begin{array}{r}179 \\
=\quad 685 \\
-\quad 529\end{array}$ & $\begin{array}{r}119 \\
-\quad 690 \\
\end{array}$ & $\begin{array}{r}189 \\
-713 \\
\end{array}$ & $\begin{array}{r}230 \\
-\quad 534 \\
\end{array}$ & $\begin{array}{r}138 \\
-\quad 681 \\
\end{array}$ \\
\hline $\begin{array}{l}13 \mathrm{a}^{1} \\
14 \\
15\end{array}$ & $\begin{array}{r}014 \\
+\quad 60 \\
+\quad 473\end{array}$ & $\begin{array}{r}-529 \\
+\quad 60 \\
488\end{array}$ & $+\overline{5}$ & $\overline{\overline{37}}$ & $\begin{array}{r}+1,688 \\
+\quad 51 \\
+\quad 437\end{array}$ & $\begin{array}{r}+1,688 \\
\quad 23 \\
+\quad 474\end{array}$ \\
\hline $\begin{array}{l}16 \\
17 \\
18 \\
19 \\
20\end{array}$ & $\begin{array}{r}+271 \\
\pm \quad 743 \\
\quad 445 \\
\pm \quad 372 \\
-\quad 261\end{array}$ & $\begin{array}{r}+221 \\
\pm \quad 727 \\
\quad 462 \\
\pm \quad 345 \\
-\quad 276\end{array}$ & $\begin{array}{r}207 \\
\pm \quad 713 \\
\quad 455 \\
+\quad 318 \\
-\quad 322\end{array}$ & $\begin{array}{r}193 \\
\pm \quad 695 \\
\quad 474 \\
\pm \quad 322 \\
-\quad 295\end{array}$ & $\begin{array}{r}+184 \\
\pm \quad 745 \\
\quad 442 \\
\pm \quad 308 \\
-\quad 262\end{array}$ & $\begin{array}{r}161 \\
\pm \quad 667 \\
\quad 400 \\
\pm \quad 363 \\
\quad 253\end{array}$ \\
\hline $\begin{array}{l}21 \\
22 \\
23 \\
24 \\
25\end{array}$ & $\begin{array}{r}+345 \\
+\quad 872 \\
+1,313 \\
+\quad 133 \\
+2,598\end{array}$ & $\begin{array}{r}+267 \\
+\quad 874 \\
+1,546 \\
+\quad 124 \\
+2,553\end{array}$ & $\begin{array}{r}+313 \\
+\quad 916 \\
+1,353 \\
+2,582\end{array}$ & $\begin{array}{r}+294 \\
+\quad 865 \\
+1,269 \\
+\quad 161 \\
+2,553\end{array}$ & $\begin{array}{r}+290 \\
+\quad 870 \\
+1,201 \\
+2,156 \\
+2,576\end{array}$ & $\begin{array}{r}+294 \\
+\quad 869 \\
+1,269 \\
+\quad 157 \\
+2,585\end{array}$ \\
\hline $\begin{array}{l}26 \\
27 \\
28\end{array}$ & $\begin{array}{r}276 \\
\pm \quad 886 \\
-\quad 913\end{array}$ & $\begin{array}{l}+272 \\
\pm 911 \\
=961\end{array}$ & $\begin{array}{r}276 \\
\mathbf{r}_{929} \\
-1,035\end{array}$ & $\begin{array}{r}267 \\
\pm \quad 883 \\
-\quad 920\end{array}$ & $\begin{array}{r}258 \\
\pm \quad 879 \\
-\quad 911\end{array}$ & $\begin{array}{r}+290 \\
\pm \quad 902 \\
-943\end{array}$ \\
\hline
\end{tabular}

${ }^{1}$ Station 13 was buried by the lava flow of May 31. A new station, 13a, was established during October.

steam, because no similar change appeared at the steam well where measuring conditions remained constant.

No temperature measurements were obtained on the lava fountains during the eruption of May 31 to June 3, because during the hours between the outbreak and daylight the crater contained too much fume for clear sights to be obtained with the optical pyrometer, and during succeeding nights the fountains were too small and inconstant to permit reliable settings of the instrument. Readings were not attempted during the morning of June 1 because previous experience had indicated that daylight readings are not reliable.

\section{RAINFALI RECORDS}

Daily readings of rainfall were continued at the gage near the Uwekahuna seismograph station throughout 1954. Gages at the Mauna Loa seismograph station and at an altitude of 5,500 feet on the Mauna Loa truck trail were read every 2 days. A rain gage 300 feet north of the southeast tilt cellar, on the floor of Kilauea caldera southeast of Halemaumau, was read once a month. The monthly totals for these gages are given in table 8 . 
TABLE 8.-Rainfall during 1954, in inches

\begin{tabular}{|c|c|c|c|c|}
\hline $\begin{array}{l}\text { Month } \\
1954\end{array}$ & Halemaumau & $\begin{array}{l}\text { Uwekahuna } \\
\text { seismograph } \\
\text { station }\end{array}$ & $\begin{array}{l}\text { Mauna Loa } \\
\text { truck trail } \\
\text { (altitude, } \\
\sigma, 500 \text { feet) }\end{array}$ & $\begin{array}{c}\text { Mauna Loa } \\
\text { seismograph } \\
\text { station }\end{array}$ \\
\hline 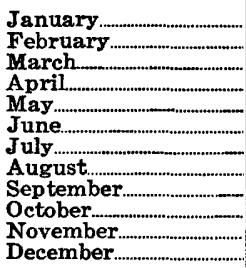 & $\begin{array}{r}2.01 \\
9.97 \\
4.47 \\
2.35 \\
2.40 \\
.54 \\
1.08 \\
2.08 \\
1.55 \\
.86 \\
16.90 \\
10.58\end{array}$ & $\begin{array}{r}3.07 \\
11.53 \\
6.10 \\
2.35 \\
3.89 \\
.95 \\
2.05 \\
3.00 \\
1.79 \\
1.32 \\
12.62 \\
13.41\end{array}$ & \begin{tabular}{r|}
$\mathbf{3 . 5 6}$ \\
11.35 \\
8.22 \\
3.44 \\
8.80 \\
.11 \\
2.51 \\
3.11 \\
2.43 \\
.93 \\
4.70 \\
7.68
\end{tabular} & $\begin{array}{r}3.87 \\
12.53 \\
8.20 \\
4.29 \\
8.66 \\
.21 \\
2.97 \\
4.47 \\
2.74 \\
1.05 \\
8.15 \\
7.83\end{array}$ \\
\hline Total & 54.79 & 62.08 & 56.84 & 59.97 \\
\hline
\end{tabular}

\section{HISTORY OF VOLCANIC CONDITIONS AND EARTHQUAKES}

January.-This was a quiet month for Hawaiian volcanoes. Only 27 earthquakes were recorded by seismographs of the Hawaiian Volcano Observatory. Seven of them originated under Kilauea, 12 under Mauna Loa, and 8 recorded too weakly to be located.

An earthquake at $21^{\mathrm{h}} 39^{\mathrm{m}}$ on January 20 , issuing from a focus 10 miles under Puu Ulaula on the northeast rift zone of Mauna Loa, was felt in the Volcano area, Hilo, Hamakua, and Kona. Two smaller earthquakes from foci under the east rift of Kilauea were felt in Hilo; the first at $4^{\mathrm{h}} 36^{\mathrm{m}}$ on January 24, and the second at $11^{\mathrm{h}} 48^{\mathrm{m}}$ on January 31 . At $2^{\mathrm{h}} 27^{\mathrm{m}}$ on January 17 , a slight earthquake was felt in Kona.

Tilting of the earth's surface measured at the Whitney Laboratory of Seismology on the northeastern rim of Kilauea caldera was southwestward at a rate normal for that season of the year. Measurements of cracks in the floor of Kilauea showed no significant changes in the volcanic pressure under the volcano.

February.-Hawaiian volcanoes remained quiet during February. Only 3 of the 27 earthquakes recorded by the Hawaiian Volcano Observatory seismographs were felt. Fourteen earthquakes originated under Mauna Loa, including those at $14^{\mathrm{h}} 49^{\mathrm{m}}$ on February $6,3^{\mathrm{h}} 15^{\mathrm{m}}$ on February 16 , and $17^{\mathrm{h}} 32^{\mathrm{m}}$ on February 22 , which were felt in Kona. Kilauea was shaken by six earthquakes, none of which was felt. Seven of the recorded earthquakes were too feeble to be located.

Tilting of the earth's surface at the northeastern rim of 
Kilauea caldera proceeded in a southwesterly direction at a rate approximately normal for that season of the year.

March.-Thirty-six earthquakes were recorded by seismographs of the Hawaiian Volcano Observatory in March. During most of the month seismic activity remained at the low level established during January and February; only 15 earthquakes were recorded from March 1-29. Nine originated at Kilauea. The remaining six, including the earthquake at $16^{\mathrm{h}} 19^{\mathrm{m}}$ on March 16, which was felt in central Kona, issued from Mauna Loa.

A series of small tremors felt in Kohala at about $20^{\mathrm{h}} 30^{\mathrm{m}}$ on March 23 was not recorded on any of the observatory's seismographs.

Two strong earthquakes, which originated at a depth of about 15 miles on the east rift zone of Kilauea or the eastward extension of the Hilina fault system between the rift zone and the south shore in the vicinity of Kalapana, rocked the island of Hawaii early on the morning of March 30. The first shock was recorded on the seismographs at the Hawaiian Volcano Observatory at $6^{\mathrm{h}} 40^{\mathrm{m}} 07^{\mathrm{s}}$; the second at $8^{\mathrm{h}} 42^{\mathrm{m}} 01^{\mathrm{s}}$. Both earthquakes were felt over the entire island of Hawaii, and at least the second, which was the larger of the two, was felt on parts of Maui Island. Extensive, but mostly moderate, damage was caused in the Hilo and Puna districts. Although the shaking was most intense in the Puna district, where water tanks were thrown down and stone fences were damaged, the most spectacular damage occurred in and near the city of Hilo, where many windows were broken and parts of a few houses were deranged or thrown down.

On March 30-31 a total of 16 aftershocks, several of which were felt in Puna and Hilo, stemmed from the same region as the two large quakes. The largest of these occurred at $6^{\mathrm{h}} 57^{\mathrm{m}}$ on March 30 and at $15^{\mathrm{h}} 04^{\mathrm{m}}$ and $16^{\mathrm{h}}$ on March 31 . The aftershock sequence extended into April; small earthquakes occurred at $15^{\mathrm{h}} 57^{\mathrm{m}}$ on April 1 and $14^{\mathrm{h}} 05^{\mathrm{m}}$ on April 8.

Concurrent with the large earthquakes in Puna and the associated aftershocks, seismic activity increased near Kilauea caldera. Four quakes originated in that region on March 30-31 and two more occurred on April 1. Of these six earthquakes, those at $11^{\mathrm{h}} 19^{\mathrm{m}}$ on March 30 and $6^{\mathrm{h}} 35^{\mathrm{m}}$ on April 1 were felt in the Volcano area.

The normal seasonal southwestward tilting at the northeastern rim of Kilauea caldera reversed for about 1 week at the time of the Puna earthquakes. Subsequently, southwestward tilting normal for that season was reestablished. 
No general change in the width of cracks in Kilauea caldera, that might indicate changing pressure under the volcano, accompanied the Puna earthquakes.

April.-Seismic activity on the island of Hawaii was appreciably greater than normal during April. A total of 69 earthquakes larger than tremors was recorded on seismographs operated by the Hawaiian Volcano Observatory. Of these, 44 originated in Kilauea volcano, 19 of them in or near the crater area, and most of the others along the east rift zone. Three of these earthquakes were felt in the Volcano area on April 15, and one each on April 1 and 22. The quake felt in Hilo on April 8 was an aftershock of the large quakes that originated in Puna on March 30. Another, felt in Hilo on April 26, had its focus on the east rift zone of Kilauea about 9 miles eastsoutheast of the caldera.

Only 6 earthquakes were definitely related to Mauna Loa, although the origins of 14 others could not be located with certainty. On April 23-24, 3 small quakes originated beneath the western slope of Hualalai volcano.

Tilting of the ground surface at the northeastern rim of Kilauea caldera was southwestward, but at a rate somewhat less than normal. This apparently represented a slight increase of volcanic pressure beneath Kilauea.

Although Kilauea volcano was definitely restless, there was as yet no indication of imminent eruption.

May.-The outstanding event of the month was the outbreak of Kilauea on May 31. The eruption is described on pages 55-68.

Earthquake activity at Kilauea remained greater than usual throughout May. The total number of quakes recorded and the weekly seismicity index ranged from 2 to 4 times the normal. Thus the volcano was obviously uneasy, but no single event or pattern of events was recognized that would make possible a definite prediction of a coming eruption. A large number of very small earthquakes recorded on the Sprengnether vertical seismograph at the Uwekahuna station may, on further analysis, prove to have characteristics that would aid prediction if similar swarms occur in the future. This was the first pre-eruption seismic activity recorded on seismographs of high sensitivity in Hawaii.

Ground tilting at the northeastern rim of Kilauea caldera was almost normal during May. However, the seasonal reversal from southward to northward tilting took place a little earlier than usual, and there was a slightly larger than usual accumulation of northward tilting during the month. There probably was a small increase of magmatic pressure beneath the caldera area. 
June.-The eruption of Kilauea that began at $4^{\mathrm{h}} 09^{\mathrm{m}}$, May 31 , ended late in the afternoon of June 3. No eruptive activity occurred during the remainder of the month. Seismic activity at Kilauea remained somewhat greater than normal throughout the month of June. The seismograph at the Whitney Laboratory of Seismology recorded a total of 65 earthquakes. Most of them came from a depth of several miles beneath the Kilauea caldera area, and represented continued uneasiness of the Kilauea volcano. Ground tilting was approximately normal for that season of the year, indicating no marked change of volcanic pressure during or following the eruption.

During June 16-20 many small quakes originated, apparently at a depth of about 25 miles, in the vicinity of the Mauna Loa seismograph station. Many of them were felt on the north and east flanks of Mauna Kea.

Several small quakes were felt in Kona during June. Two of these, on June 1 and 16, dismantled the seismograph at Konawaena School. The quakes originated in central Kona, probably on the Kealakekua fault.

Starting early on the morning of May 31, and continuing throughout June, many landslides occurred on the walls of Halemaumau crater. More broken rock accumulated at the foot of the wall during June than during the entire interval between the 1952 and 1954 eruptions. Several segments of the crater rim collapsed, one of which was almost directly in front of the visitors' overlook. The greatest instability was on the northern wall, where the rim collapsed for a distance of several hundred feet, and an average width of about 10 feet. One bench mark and several other surveying stations used by the Hawaiian Volcano Observatory were lost. Cracks near the northern rim show an opening of about 1 foot. Less-pronounced cracking occurred on the caldera floor southeast, south, and west of Halemaumau. The crack at station 40 , west of the west tilt cellar, opened $9 \mathrm{~mm}$ during June.

The summit region and northeast rift zone of Mauna Loa were examined June 24-27. No signs of any unusual conditions were detected. There have been no apparent changes in Mokuaweoweo caldera since the end of the 1949 eruption.

July.-Earthquake activity on the island of Hawaii continued somewhat greater than usual throughout July. The seismograph at the Whitney Laboratory of Seismology recorded 58 quakes during the month. This is about twice the usual number during times of volcanic quiet. The more sensitive Sprengnether seismograph at the Uwekahuna station recorded a much larger number of very small earthquakes. 
Mast of the quakes originated within a few miles of the Whitney and Uwekahuna stations, probably beneath Kilauea caldera and the east rift zone near the caldera. On July 3, at $11^{\mathrm{h}} 53^{\mathrm{m}}$, a strong earthquake was widely felt over the southern part of the island, and did minor damage in Hilo. Its epicenter was about a mile north of Alae Crater, 5 miles southeast of the caldera. J. B. Wosky, superintendent of Hawaii National Park, reported that during and after the quake numerous heavy rock falls occurred on the seaward face of Puu Kapukapu, at the coast south of Kilauea caldera. Other small shocks of this group were felt lightly in the Volcano area on July 25-26.

Several small earthquakes, originating farther east on the Kilauea rift zone, were recorded at the Pahoa station. A light quake, probably of local origin, was felt in central Kona on July 29.

Tilting of the ground surface at the northeast edge of Kilauea caldera was northward at a rate slightly greater than usual for that time of year, probably indicating a further small increase in magmatic pressure beneath the summit of the mountain.

A few rock falls continued on the walls of Halemaumau crater, but their frequency during the latter half of July was somewhat less than during June. Fresh cracking of the ground surface was observed near the western, southeastern, and northern rims of Halemaumau.

August.-Kilauea volcano continued somewhat uneasy during August. The seismograph at the Whitney Laboratory of Seismology recorded 46 earthquakes during the month. The number slightly exceeds that normally recorded in times of volcanic quiet. Most of the quakes originated beneath or near Kilauea caldera. Tilting of the ground at the northeastern rim of the caldera was northward at a rate slightly greater than usual at that season.

A sharp earthquake was felt in Kona at $23^{\mathrm{h}} 27^{\mathrm{m}}$ on August 1. Its origin was within a few miles of the seismograph station at Konawaena School, probably on the Kealakekua fault near the north edge of Kealakekua Bay. At $14^{\mathrm{h}} 27^{\mathrm{m}}$ on August 7 a strong quake originated beneath Kilauea caldera. It was felt by many persons in the Volcano area, and by some in Hilo and Kona. A moderate quake at $23^{\mathrm{h}} 16^{\mathrm{m}}$ on August 30 , felt by residents of the Volcano area, also originated beneath Kilauea caldera.

September.-The seismograph at the Whitney Laboratory of Seismology recorded 94 earthquakes during the month, approximately 3 times the number recorded in normal times of volcanic quiet. During the week starting September 12, 56 quakes were recorded. Most of the earthquakes apparently originated beneath 
the Kilauea caldera area or the adjacent part of the east rift zone. Several during mid-September probably originated at depths of 25 to 30 miles beneath the caldera or the nearby slope of Mauna Loa. An earthquake which occurred at $2^{\mathrm{h}} 43^{\mathrm{m}}$ on September 13 was felt in Hilo.

Several quakes were felt in Kona during early September. These originated on the western slope of Mauna Loa, probably on the Kealakekua fault. No other signs of uneasiness of Mauna Loa were noted.

Tilting of the ground at the northeastern rim of Kilauea caldera was almost normal in direction and amount for that season of the year. Thus no marked change in volcanic pressure beneath Kilauea was indicated. Neither during the May-June eruption of Kilauea, nor in the 4 months after the eruption, was there any indication of reduction of volcanic pressure beneath Kilauea volcano. Magma appeared to still be standing at a high level in the conduit. Under such conditions, it was possible that eruption might occur with little or no warning other than the numerous earthquakes that indicate continued uneasiness of the volcano. This possibility was pointed out in press releases issued early in October 1954 and January 1955.

October.-Kilauea volcano remained in a restless condition during October. About two-thirds of the 70 earthquakes recorded on the seismograph at the Whitney Laboratory of Seismology stemmed from the region of Kilauea caldera and the adjacent part of the east rift zone. None of these earthquakes was reported felt.

Approximately one-third of the earthquakes recorded during the month originated beneath Mauna Loa. Among these were the four earthquakes reported felt on Hawaii during October. At $22^{\mathrm{h}} 50^{\mathrm{m}}$ on October 7 the southern part of the island was shaken by an earthquake with its epicenter about 10 miles north of Naalehu. The largest quake of the month, which occurred in central Kona at $6^{\mathrm{h}} 26^{\mathrm{m}}$ on October 11, was felt over most of the island. Two aftershocks, the first at $6^{\mathrm{h}} 39^{\mathrm{m}}$ and the second at $6^{\mathrm{h}} 52^{\mathrm{m}}$ on October 11, were felt in south Kona.

Tilting of the ground at the northeastern rim of Kilauea caldera was about normal in direction and amount for that season of the year.

November.-Kilauea volcano continued moderately uneasy throughout November. The seismograph at the Whitney Laboratory of Seismology recorded 72 earthquakes during the month. The more sensitive seismograph at the Uwekahuna station recorded approximately 385 quakes. Both the total number of earthquakes and the amount of energy released in earthquakes were 
approximately three times as great as during periods of volcanic quiet.

Most of the earthquakes that could be located came from points of origin near Kilauea caldera. Two of them, at $23^{\mathrm{h}} 09^{\mathrm{m}}$ on November 23 and $11^{\mathrm{h}} 34^{\mathrm{m}}$ on November 26, were felt in the Volcano area. Two other quakes, felt at Kamuela at $10^{\mathrm{h}} 56^{\mathrm{m}}$ on November 19 and $15^{\mathrm{h}} 02^{\mathrm{m}}$ on November 20 , appear to have come from a depth of about 20 miles beneath the northwest flank of Mauna Kea, 10 miles southeast of Kamuela. On November 21, a small quake came from a shallow focus 3 miles south-southeast of the summit of Mauna Loa.

Tilting of the ground at the northeastern rim of Kilauea caldera was about normal during most of the month. However, from November 27 to 30 it was northeastward at a rate decidedly greater than normal. This may have been related to heavy rains rather than to an increase of volcanic pressure.

December.-Kilauea volcano continued uneasy throughout December. The seismograph at the Whitney Laboratory recorded 91 earthquakes, more than twice the number normally recorded during times of volcanic quiet. The local seismicity was more than three times as great as that normally experienced during quiet periods. The strain-release index also was high. The more sensitive seismograph at the Uwekahuna station recorded 353 earthquakes. Most of the quakes originated at or close to Kilauea caldera. Several interesting quakes came from foci about 28 miles beneath the caldera. Others were of exceedingly shallow origin.

Many earthquakes also originated along the east rift zone of Kilauea volcano, both in the vicinity of the Chain of Craters Road in Hawaii National Park, and in east Puna. Many small quakes, and a few fairly large ones, came from foci only about 5 miles from the Pahoa seismograph station. The Pahoa seismograph was dismantled by the quakes several times during the month. Two of them, at $11^{\mathrm{h}}$ and $16^{\mathrm{h}} 02^{\mathrm{m}}$ on December 14, were felt strongly 4.5 miles east-southeast of Pahoa. It is noteworthy that this locality is very close to the point of the original outbreak of the 1955 eruption.

An earthquake at $14^{\mathrm{h}} 30^{\mathrm{m}}$ on December 4 , felt by some persons from Hilo to Pahala, originated about 10 miles beneath the south flank of Kilauea just south of the caldera. A quake felt slightly in central Kona and Pahala at $20^{\mathrm{h}} 59^{\mathrm{m}}$ on December 5, and another felt in the Volcano area at $22^{\mathrm{h}} 26^{\mathrm{m}}$ on December 14, originated beneath Kilauea caldera. Another, felt in the Volcano district at $8^{\mathrm{h}} 49^{\mathrm{m}}$ on December 28, apparently stemmed from the Kaoiki fault, which separates Kilauea and Mauna Loa. 
Quakes felt in Kona at $19^{\mathrm{h}} 15^{\mathrm{m}}$ on December $6,18^{\mathrm{b}}$ on December 11 , and $21^{\mathrm{h}} 10^{\mathrm{m}}$ on December 24 , probably came from foci beneath the west flank of Mauna Loa. A quake felt in Kamuela and Kohala at $12^{\mathrm{h}} 46^{\mathrm{m}}$ on December 23 originated near Kamuela.

Particularly noteworthy volcanologically, although they were felt by no one, were several periods of almost continuous small earthquakes recorded at the Mauna Loa and Uwekahuna stations. The longest of these periods extended from $14^{\mathrm{b}}$ on December 3 to $9^{\mathrm{h}} 45^{\mathrm{m}}$ on December 4 . Other shorter periods of this continuous spasmodic tremor, from 10 minutes to more than half an hour in duration, occurred at intervals from November 30 to December 5 , and on December 21. These quakes apparently came from a depth of 25 to 30 miles beneath the Kilauea caldera area.

Tilting of the ground surface at the northeast edge of Kilauea caldera was slightly southwestward during the month. Because the normal tilting at that season is slightly northeastward, this evidence indicated the possibility of a slight decrease in magmatic pressure beneath Kilauea. However, the reversal to southwestward tilting normally takes place in January, and exceptionally heavy rains during December may have had enough effect on the temperature of the rocks near the seismograph station to cause the reversal to southwestward tilting to occur a little earlier than usual, independently of any volcanic effect. Tiltmeters at Uwekahuna and on the caldera floor showed no appreciable centripetal tilting.

Although Kilauea volcano showed definite signs of uneasiness, there was at the end of December no definite evidence that eruption was imminent. However, conditions somewhat resembled those preceding the eruption on May 31, and there was little or no evidence of any reduction in pressure since before the May eruption. A press release issued on January 6, 1955, stated: "Molten lava may still be standing at high levels in the conduit of the volcano, and it is not unlikely that eruption might again occur with little or no additional forewarning."

\section{PNEUMATOLYTIC DEPOSITION AND ALTERATION} ON THE FLOOR OF KILAUEA CALDERA

Gases rising through innumerable fissures in the lavas that floor Kilauea caldera have formed white deposits on the surface of the lava. These deposits are not distributed uniformly on the caldera floor, but are concentrated in narrow bands and irregular patches. For the most part, the active steam vents are confined to the same areas. With certain qualities of lighting, the areas of 
deposition show up clearly to the eye in the field, from the caldera rim, and in aerial photographs. The mapping of these areas was commenced by plane table in 1951, but the work was interrupted by the heavy earthquake of August 21, in Kona. It was completed in January 1955, by use of a photomosaic compiled by former chief ranger E. K. Field, of Hawaii National Park, from aerial photographs taken in 1944.

Gases issuing at the two solfataras, known respectively as Sulphur Bank and the southeast sulfur bank (fig. 10), contain sulfur dioxide and carbon dioxide. In those two areas of acid-gas release the rocks are much altered to iron oxides and clay minerals, and leached to form pseudomorphs of opaline silica (Macdonald, 1944). For the most part, however, the fumarole gases in and near Kilauea caldera consist largely or entirely of steam and air.

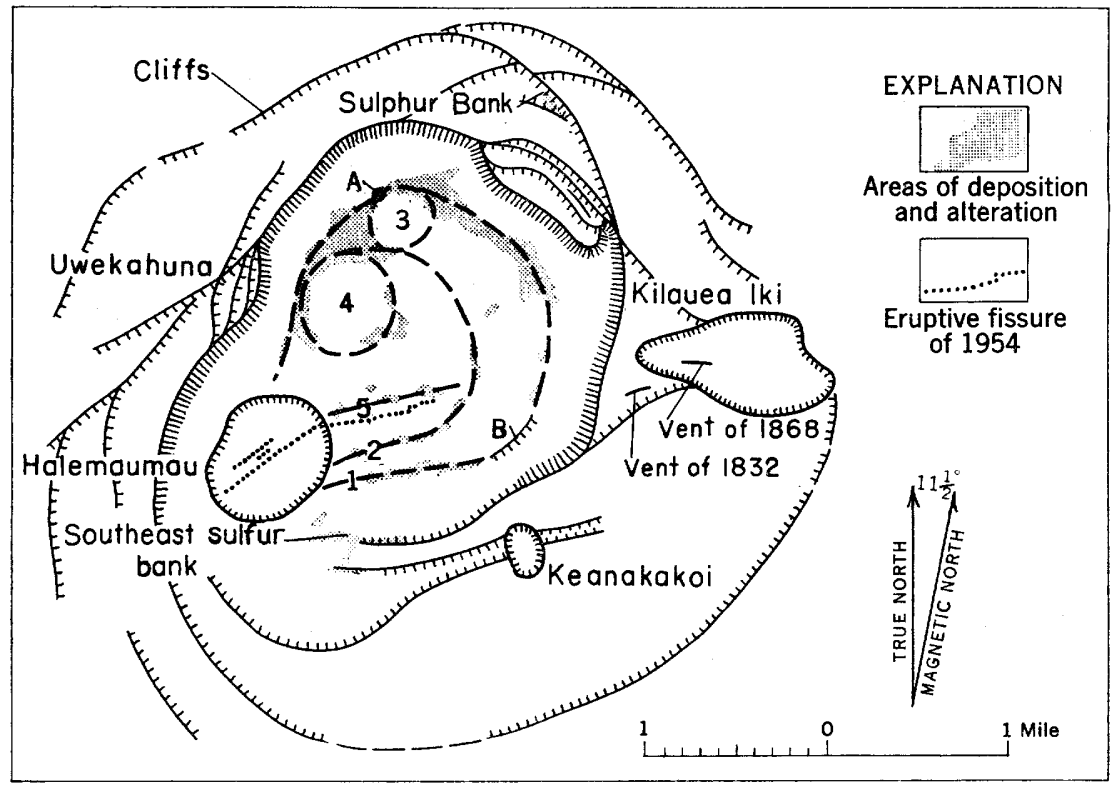

FIGURE 10.-Map of Kilauea caldera showing areas of pneumatolytic deposition and alteration, the Perret steam vent $(A)$, and a small monoclinal scarp $(B)$ on one of the arcuate lineaments marked by the areas of deposition. Trace 1 appears to coincide with the margin of the basin of 1840 (fig. 11); 2 resembles the debris ridge of $1846 ; 3$ coincides with the position of the north embayment of the 1823 basin; and 4 with the west embayment of the 1840 basin. Trace 5 and the vents of 1832 and 1868 appear to be related to the east rift zone. Topographic control from U. S. Geological Survey quadrangle maps, scale 1:31,680, surveyed 1913, 1922 .

Along the source fissure of the 1954 lava flow on the caldera floor northeast of Halemaumau (fig. 10) small deposits of thenardite $\left(\mathrm{Na}_{2} \mathrm{SO}_{4}\right)$ are found, associated with a little opal. These 
resemble deposits along eruptive fissures on Mauna Loa (Macdonald and Wentworth, 1954, p. 180). At other areas within Kilauea caldera the deposits appear to be entirely opal. The opal is white and powdery, and forms thin crusts commonly in mammilary, botryoidal, and stalagmitic forms, and rarely miniature conelets less than a centimeter high resembling geyser cones. Below the crust the lava rocks are generally partly altered to clay minerals and iron oxides for thicknesses of a few millimeters or a few centimeters. Generally the line of demarcation between the altered rock and the overlying crust is very sharp. The silica has clearly been transported and deposited by the rising steam, though it probably was derived by leaching of the altered rocks along the walls of the channel rather than from any deep-seated magmatic source.

Most of the areas of pneumatolytic deposition on the caldera floor show a strikingly arcuate arrangement (fig. 10). With little question, these arcuate traces mark the buried margins of the sunken central basins that existed in the caldera during the 19th century. The buried scarps that bounded the basins, and the faults beneath them on which the sinking took place, still constitute pathways that guide the rise of steam from greater depths.

Comparison with figure 11 demonstrates that trace 1 (fig. 10) coincides approximately with the margin of the inner basin of 1840. Trace 2 nearly corresponds with the ridge of talus pushed up by bodily elevation of the central part of the caldera floor in 1845-46, and may correspond with the central basin of 1868 . Trace 3 coincides in position with the embayment at the north edge of the inner basins of 1823 (fig. 11), and 1840 (Wilkes, 1845, map facing p. 165). Trace 4 appears probably to reflect the position of another small pit, possibly the lake shown north of Halemaumau in Malden's map of 1825 (Brigham, 1909, p. 45) and the sketch by Captains Parker and Chase in 1838 (Brigham, 1909, p. 48 ), and the embayment on the west side of the central basin shown in Wilkes' map of 1841 .

Along trace 1, in the southeastern part of the caldera, a scarp (B, fig. 10) as much as 10 feet high, formed principally by flexing of the lavas with cracking and minor faulting, has resulted from uplift of the central part of the crater floor in relation to the margin. This uplift probably took place since 1884, because the lavas covering that part of the floor probably are of that date.

Trace 5 appears to be essentially straight, rather than arcuate. It coincides closely in direction, and very nearly in position, with the eruptive fissure of the 1954 lava flow (pl. 1), and probably represents the northeast rift zone crossing the caldera floor. 


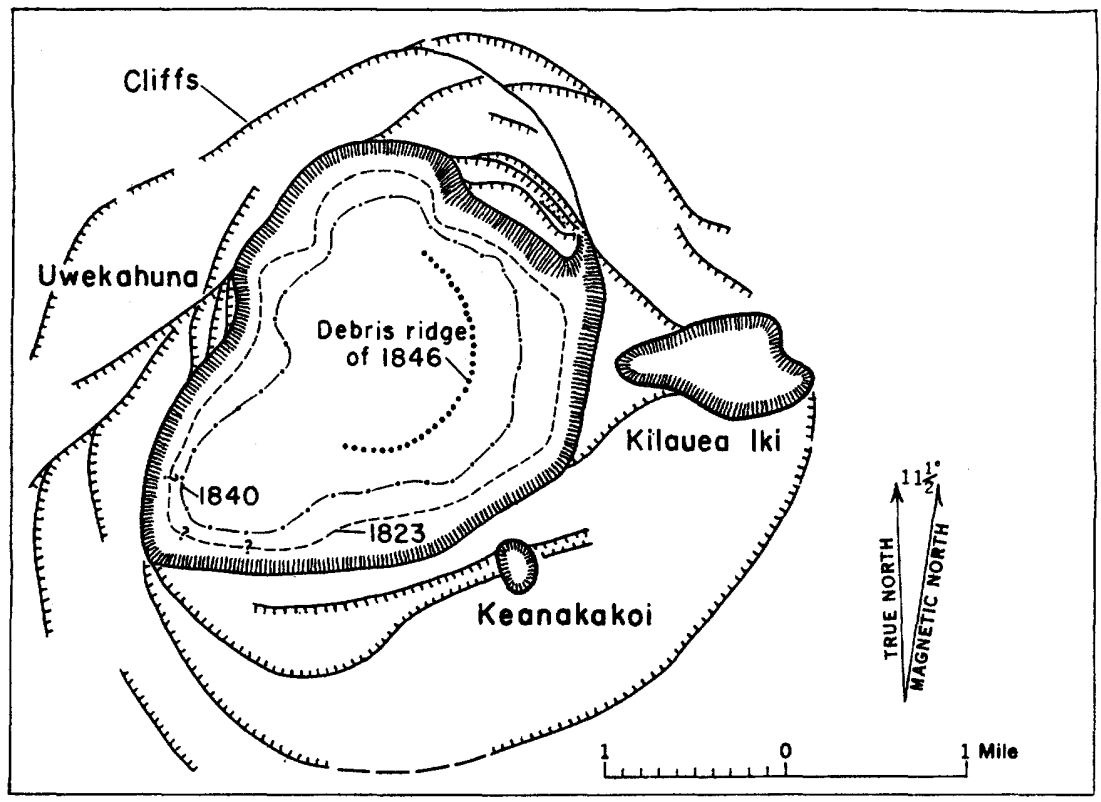

FIGURE 11.-Map of Kilauea caldera showing the approximate margin of the inner depression in 1823 (adapted from the map by Malden in 1825), and in 1840 (after Wilkes), and the approximate position of the ridge of elevated talus in 1846 (after $\mathrm{C}$. $\mathrm{S}$. Lyman in Brigham, 1909, p. 59, 60).

The eruptions of 1832 and 1868 no doubt represent activity on this rift zone.

Strikingly linear also is the arrangement of the three small circular structures, pits 3 and 4 and Halemaumau. The trend of this lineament departs somewhat from that of the southwest rift zone, and even more than that of the northeast rift. It is, however about the same as that of two dikes cropping out in the caldera wall west of the fault blocks at the northeast edge of the caldera. These dikes are the only ones exposed in the walls of Kilauea caldera other than those in Halemaumau.

\section{THE EAST PUNA EARTHQUAKES OF MARCH 30, 1954}

The strongest earthquakes felt on Hawaii since the Kona earthquake of August 21, 1951, rocked the entire island early on March 30. A foreshock at $6^{\mathrm{h}} 40^{\mathrm{m}}$ shook down several domestic water storage tanks in Kalapana and Opihikao. Stone fences along the Puna coast between these two towns were damaged slightly at the time of the first earthquake, but this damage cannot be separated from that caused by the larger earthquake which fol- 
lowed. In Hilo a few dishes were broken and small objects were overturned. Only a few residents at the north end of the island felt this earthquake.

At $8^{\mathrm{b}} 42^{\mathrm{m}}$ a stronger earthquake issued from the same region. Two miles west of Kalapana one man was gathering up the pieces of a water tank, collapsed by the first earthquake, that had stood next to his house. The second earthquake rocked the house so severely that he was afraid it would fall. He tried to move away to safety; but so violent was the pitching of the ground, he reported, that a normal walk was impossible, and he moved by a series of leaps with both feet together. The house did not fall.

About 2 miles north of Kalapana a rancher and his men were repairing stone fences damaged by the first earthquake when the second struck. A loud rumbling sound preceded the shaking by about 2 seconds. The rapid, jerking motion of the earth that followed made standing difficult. Almost all the stone fences extending from east to west (perpendicular to the slope of the ground) collapsed into low mounds of rock that were as wide as they were high. North-south fences were damaged only slightly.

Stone fences along the coast from Kalapana to Opihikao were damaged moderately. Rock slid from low embankments into the road between Kalapana and Pahoa for a distance of 3 miles inland from the coast.

In Hawaii National Park minor cracks opened in the Chain of Craters road next to several of the pit craters. Two slides poured from the northern rim of Kilauea caldera, and Halemaumau crater filled with dust as many small slides were shaken loose around the rim. At the observatory the motion was a strong, slow pitching of the ground. Although standing was not difficult during even the strongest shaking, which lasted about 1 minute, one's instinct was to clutch for support as walls swayed visibly. Motion of the earth was perceptible for at least 2 minutes.

In Hilo, windows were broken and several buildings received minor structural damage. Operators in the control tower at General Lyman Airport reported seeing earth waves rolling across the runways.

The main earthquake was felt in Haleakala Crater on Maui, and by at least two persons on Oahu.

Earthquake intensity questionnaires were completed by principals in the public schools on Hawaii and by high school science teachers throughout the islands. The kind cooperation of these principals and teachers is gratefully acknowledged. The data from these questionnaires permitted the assignment of intensities (modified Mercalli) to most of the communities around the 
populated perimeters of the islands. Little information could be found on the effects of the earthquakes in the interior regions of the island of Hawaii, especially in the uninhabited area west of the epicentral tract. Isoseismal lines based on all the information available were drawn for the main earthquake and are shown in figure 2.

An intensity of VIII was assigned to a small region north of Kalapana on the basis of extensive damage to stone fences in that area. The elongation of the isoseismal curves parallel to the coast is based on the uniformly moderate damage to stone fences throughout this region. Deep ash soil on the slopes of Mauna Kea along the Hamakua coast north of Hilo induced higher intensities than were observed at comparable distances from the epicentral area on Mauna Loa and Kilauea.

Both the main earthquake and the foreshock dismantled all seismographs on the island of Hawaii except the low magnification Imamura and the optically recording Sprengnether at Uwekahuna. At all stations the motion in the preliminary waves was so large that the instrument either dismantled before the secondary waves arrived, or was recording such large amplitudes by the time that phase arrived that it could not be identified with certainty. Because accurate clocks and radio time-marking circuits had not been installed in the Hilo and Kona stations at that date, absolute arrival times of the primary waves at those stations were not available. Thus, the data were not adequate for determining the distance of the epicenter from each station; so the usual methods of locating the epicenter could not be used.

The first few primary waves were recorded clearly at the Whitney Laboratory of Seismology and at Hilo, the two stations nearest to the most severely shaken area. As those stations are equipped with two-component horizontal seismographs, the recorded amplitudes permitted the calculation of the direction of earth motion caused by the primary waves at each station. This motion lies along a line connecting the station and epicenter. Projecting the direction of earth motion recorded at those two stations toward the epicentral area, the intersection of the projected lines is at the epicenter.

For the foreshock at $6^{\mathrm{h}} 40^{\mathrm{m}}$ this intersection was 3.5 miles northwest of Kalapana; for the main earthquake at $8^{\mathrm{h}} 42^{\mathrm{m}}$ it was 2 miles west of Kalapana. A point about midway between these two intersections, at $19^{\circ} 21^{\prime} \mathrm{N} ., 155^{\circ} \mathrm{W}$., was adopted as the instrumental epicenter for both earthquakes. Using this epicenter and the arrival times of the preliminary waves at the Whitney Laboratory of Seismology, the origin times for the foreshock 
and the main earthquake were, respectively, $06^{\mathrm{h}} 40^{\mathrm{m}} 02^{\mathrm{s}}$ and $08^{\mathrm{b}} 41^{\mathrm{m}} 56^{\mathrm{s}}$, Hawaiian standard time.

The California Institute of Technology estimated the magnitude of the main earthquake to be 6.5 , and that of the foreshock to be 6 .

On March 30-31 a total of 16 aftershocks, several of which were felt in Puna and in Hilo, stemmed from the same region as the two large earthquakes. The largest ones occurred at $6^{\mathrm{h}} 57^{\mathrm{m}}$ on March 30 and at $15^{\mathrm{h}} 04^{\mathrm{m}}$ and $16^{\mathrm{h}}$ on March 31 . The aftershock sequence extended into April, with small earthquakes at $15^{\mathrm{h}} 57^{\mathrm{m}}$ on April 1 and at $14^{\mathrm{h}} 05^{\mathrm{m}}$ on April 8. Epicenters for the aftershocks were obtained by the usual $S-P$ method. At most stations the beginning of the primary waves was indistinct, and the epicenters obtained were only approximate. However, they did confirm the epicenter obtained for the main earthquake and foreshock.

The instrumental epicenter of the large earthquake lies in the region of highest intensity (fig. 2) between the east rift zone of Kilauea and the south shore of the island. Both earthquakes probably originated on one of the prominent normal faults in that region.

Exactly what relationship exists between these earthquakes and subsequent eruptions of Kilauea is not clear. Several hours after these earthquakes, a separate sequence of earthquakes began in and around Kilauea caldera. This latter sequence continued through the May 31, 1954, eruption in Kilauea caldera and did not stop until after the eruption on the east rift zone of Kilauea between February and May, 1955. Earthquakes premonitory to the latter eruption stemmed from the east rift zone of Kilauea about 10 miles northeast of the epicenter of the large earthquake of March 30, 1954.

\section{THE 1954 ERUPTION OF KILAUEA VOLCANO}

Kilauea volcano erupted early on the morning of May 31, 1954, after a dormancy of $181 / 2$ months. Although it could not be specifically predicted, the eruption was not unexpected. The termination of activity at Kilauea in November 1952, was neither accompanied nor followed by any abnormal tilting that would indicate reduction of volcanic pressure beneath the volcano. On the contrary, during 1953 there was an accumulation of approximately 12 seconds of northward tilting in excess of the usual seasonal tilting at the Whitney Laboratory of Seismology on the northeastern rim of Kilauea caldera. This evidence indicated an actual increase of volcanic pressure beneath the caldera, re- 
sulting in a tumescence of Kilauea volcano. Short periods of volcanic tremor during February and March 1953, indicated subsurface movement of lava at Kilauea. All indications were that molten lava continued to stand at a high level within the conduit. In the report on activity of Hawaiian volcanoes during 1953, submitted to the U. S. Geological Survey in mid-May 1954, it was stated (Macdonald and Eaton, 1955, p. 143) : "Under such conditions, eruption might come with very little forewarning."

Kilauea continued restless through the early months of 1954, but although eruption remained a possibility at any time, there was no evidence that appeared adequate as the basis of a prediction of an outbreak at any specific time.

\section{NARRATIVE OF THE ERUPTION}

Numerous small earthquakes occurred during the night of May 30-31. Slight earthquakes were recorded at $3^{\mathrm{h}} 42^{\mathrm{m}}$ and $3^{\mathrm{h}} 47^{\mathrm{m}}$ on May 31. These wakened many persons, including the writers, in the region near Kilauea caldera. Shortly afterward Macdonald noticed a faint, persistent low-pitched roaring, almost a felt vibration rather than a recognizable sound, somewhat resembling the vibration caused by a heavy truck in low gear climbing a distant hill. The sensation continued as long as the observer remained motionless. A moderate earthquake occurred at $3^{\mathrm{h}} 51^{\mathrm{m}}$ followed by a strong quake at $3^{\mathrm{n}} 54^{\mathrm{m}}$. The latter was violent enough to dismantle the Bosch-Omori seismograph, and we went immediately to the Whitney Laboratory of Seismology to restore the instrument to operation.

Halemaumau had been visited at approximately $3^{\mathrm{n}} 30^{\mathrm{m}}$ by $\mathrm{G}$. $\mathrm{H}$. Ruhle, naturalist of Hawaii National Park, who reports that complete darkness reigned and everything appeared as usual. When we reached the seismograph vault, at approximately $4^{\mathrm{h}} 03^{\mathrm{m}}$, there still was no sign of glow at Halemaumau. The seismograph was restored to operation, and a drum bearing a new record sheet placed on the instrument at $4^{\mathrm{h}} 08^{\mathrm{m}}$. At $4^{\mathrm{h}} 09^{\mathrm{m}}$ we observed the beginning of registration of volcanic tremor on the seismograph. Rushing from the vault, we saw (at approximately $4^{\mathrm{b}} 10^{\mathrm{m}}$ ) a bright glow at Halemaumau, reflected on a rising cloud of gas that already had reached a height of about 2,000 feet above the crater rim. The fume cloud continued to expand upward. About daylight the pilot of a plane inbound to Hilo reported the cloud had reached a height of 30,000 feet, where it was spreading out like a great mushroom.

We reached the Hawaiian Volcano Observatory at about $4^{\mathrm{n}} 20^{\mathrm{m}}$. Half a mile away, a dense column of fume was rising from the 
northeastern part of Halemaumau crater, nearly hiding the top of a giant lava fountain that appeared intermittently, its top reaching about 100 feet above the rim of the crater. This fountain rose from the crater floor, 470 feet below the rim. Thus, its total height was between 550 and 600 feet. Thin fume rose from the entire area of the crater with a denser column rising from the big northeast lava fountain and a second principal fume column near the southwest edge of the crater. These columns of fume rose almost vertically above the crater. There was little lowlying fume, such as made approach to the lee side of the crater almost impossible in June 1952.

At $4^{\mathrm{h}} 27^{\mathrm{m}}$ the eruptive activity was entirely confined to Halemaumau crater. Between $4^{\mathrm{h}} 30^{\mathrm{m}}$ and $4^{\mathrm{h}} 35^{\mathrm{m}}$ lava issued from a fissure on the floor of Kilauea caldera northeast of Halemaumau. Ranger D. J. Tobin, Jr., of Hawaii National Park, viewed this vent from a point near Kilauea Iki, nearly in line with the opening fissure. He states that at first the incandescent lava welled out gently, with little or no fountaining, followed by a gradual waxing of the fountains to a height of 50 to 100 feet. Because of the fume rising from Halemaumau immediately behind the new outbreak, he was unable to tell whether the arrival of lava at the surface was preceded by an outburst of fume from the fissure outside Halemaumau.

At $4^{\mathrm{h}} 35^{\mathrm{m}}$ the line of fountains on the caldera floor northeast of Halemaumau was estimated to be 300 feet long, with its west end about 300 feet from the rim of Halemaumau. During the next few minutes the fountain chain spread rapidly, mostly eastward but also slightly toward the west. By $4^{\mathrm{h}} 50^{\mathrm{m}}$ the principal chain was 1,400 feet long. Three other, shorter chains were active farther east-northeast (pls. 1 and $2 A$ ). Very active flows of pahoehoe were spreading from the base of the fountains, and had already reached lengths as great as 1,000 feet.

We reached the rim of Halemaumau crater at approximately $4^{\mathrm{h}} 55^{\mathrm{m}}$. The entire crater floor was covered with a pond of incandescent lava. Across the floor diagonally from east-northeast to west-southwest, approximately along the line of the eruptive fissures of 1952, stretched a row of lava fountains from a few feet to more than 100 feet high (pl. 1). The fissure bisected the cones left by the 1952 eruption, and lava poured from the cones into the surrounding pool. At the southwest end of the line, approximately in the position occupied by the principal fountain during the early days of the 1952 eruption (Macdonald, 1955), was a fountain 250 to 300 feet high (pl. $2 B$ ). At the northeast end the huge fountain visible earlier from the Hawaiian Volcano Ob- 
servatory continued to play to a height at least 100 feet above the observers' heads (pl. $3 A$ ). Between these two end fountains the row of smaller fountains was nearly continuous.

Northwest of the principal row of fountains lay another, shorter row, parallel to the first, and extending just northwest of the 1952 cones. Between these two rows of fountains was a third short row of three fountains, just northeast of the 1952 cones (pl. 1). All the fountains of the second and third rows were small. Few of them exceeded 10 feet, and none exceeded 25 feet in height.

Possibly the most spectacular feature of the eruption was the cascade of brilliant orange-yellow lava that poured from the eruptive fissure 300 feet above the floor, on the northeastern wall of the crater (pl. $3 A$ ). Plunging down the wall, this "fire-fall" of incandescent liquid joined the turbulent pool around the base of the northeastern fountain. The lava issued at the head of the cascade quietly, with little spattering and no fountaining, as though it were poor in gas. At the base of the cascade a row of small fountains issued from the eruptive fissure, merging southward with the big northeast fountain.

Spreading out from the rows of source fountains, the lava was quickly covered with a thin black crust that was rifted apart by movement to reveal in a network of cracks the bright orange liquid beneath. Distinct waves, set up by surging at the fountains, swept outward across the surface of the lake. At the foot of the crater walls, the surging liquid alternately covered and revealed a bright band 5 to 10 feet in height. Locally, foundering of fragments of the crust resulted in small secondary fountains, apparently caused by release of air and other gases carried down by the sinking crusts. Many of the secondary fountains were evanescent, and shifting in position. Others, however, played persistently along certain lines, apparently determined by the boundaries of flow units in the lake of liquid lava. The most prominent line of that sort extended from the southeast to northwest edges of the lake, passing just northeast of the 1952 cones, and apparently marked the boundary between two principal convective cells surrounding the southwest and northeast fountains respectively.

A gap of 200 feet separated the westernmost fountains on the caldera floor from the rim of Halemaumau crater (pls. 1 and 2A). By $5^{\mathrm{h}} 40^{\mathrm{m}}$, lava liberation had nearly ceased along the westernmost 100 feet of the fountain chain, and activity at those vents consisted largely of roaring gas release, accompanied by showers of incandescent ejecta. The preponderance of gas at those vents, together with the gas-poor character of the lava forming the cascade on the adjacent wall of Halemaumau, suggests that in the section 
of the fissure near Halemaumau there was a partial separation of the gas and liquid phase, the gas-rich portion rising nearly vertically to feed the westernmost vents of the fountain chain on the caldera floor, and the liquid largely draining into Halemaumau, forming the cascade.

No conspicuous crack was visible on the wall of Halemaumau above the head of the cascade, or between the rim of Halemaumau and the end of the fountain chain to the east. In the latter gap there were many cracks in a zone about 50 feet wide along the projected course of the eruptive fissure farther east, but none of them was continuous for more than a few feet, or was more than 2 or 3 millimeters wide.

Eastward, the principal line of fountains was about 1,400 feet long, and essentially continuous. The fountains forming this "curtain of fire" were a few feet to about 100 feet high (pl. $3 B$ ), and the accumulation of ejecta from them rapidly built a spatter rampart. Fragments of ejected pumice were drifted southwestward by the trade wind, and partly mantled the southern slope of the spatter rampart and the adjacent lava. Along its southwestern part the rampart was breached, and several flow units were escaping northwestward, merging into a single, very active flow of pahoehoe. A smaller flow moved southwestward on the south side of the rampart. A large lava river issued from the fountain pit at the east end of the spatter rampart and moved southeastward, spreading out to form a broad flow that merged with the lava flowing eastward north of the spatter rampart and with other lava from vents farther east.

Three other short rows of small fountains, less than 20 feet high, lay respectively 200,400 , and 900 feet east of the principal fountain chain. These also built small ramparts and cones of spatter, and liberated small flows. A somewhat more conspicuous row of fountains, 300 feet long, lay 1,800 feet east of the principal fountain chain. All these short rows of fountains were essentially parallel to the principal chain, but were offset en echelon from it. West of the easternmost row a zone of narrow diagonal cracks extends across an embayment in the new flow toward the next group of vents. Another zone of narrow cracks extends eastward for about 900 feet beyond the new lava, as a prolongation of the line of the principal fountain-chain (pl. 1).

By $6^{\mathrm{b}} 45^{\mathrm{m}}$ new lava had accumulated to a depth of more than 50 feet in Halemaumau crater, nearly burying the cones of the 1952 eruption. Dense, bluish-white fume filled the crater, nearly obscuring the floor. Two principal fume columns rose from the northeast and southwest fountains. Strong winds, which were 
directed centripetally entirely around the crater blew these fume columns inward, causing them to meet a few hundred feet above the crater rim. Above that level the fume cloud rose nearly vertically. No doubt the violent centripetal winds were caused by the strong convective rise of warm air and fume from the crater. Small, violent whirlwinds caused dustdevils around the edge of the crater, and whirled across the crater floor, carrying fragments of the thin crust of the lava lake.

At $7^{\mathrm{h}} 10^{\mathrm{m}}$ a good view of the northeastern part of the crater floor was obtained by Eaton from the northern rim. The northeast fountain consisted of a surging, dense, domical core rising about 200 feet above the crater floor, with frequent bursts of scattered incandescent ejecta as high as the crater rim. The main outward flowage from the base of the fountain was southward. Concentric lobe-shaped markings on the crust of the new lava formed around the base of the fountain. These were stretched outward as the current spread from the fountain source at a velocity of 5 to 10 miles per hour. The circulation appeared to move in a circle and return toward the northwest base of the fountain, but dense fume caused poor visibility of that part of the floor.

At $7^{\mathrm{h}} 30^{\mathrm{m}}$ fountain activity was decreasing both in Halemaumau and on the caldera floor to the northeast. The largest fountains northeast of Halemaumau were only about 75 feet high, and the westernmost 200 feet of the eruptive fissure was almost inactive. The southwest fountain in Halemaumau was about 150 feet high, with infrequent bursts reaching 200 feet. The northeast fountain was about 450 feet high. Other small fountains 10 to 50 feet high, were active in the central part of the floor. The cascade had dwindled to a mere trickle, and by $8^{\mathrm{h}}$ it was entirely inactive.

Between $8^{\mathrm{h}}$ and $9^{\mathrm{h}}$ the flow on the caldera floor was still advancing slowly, but had reached nearly its full extent. The three segments of eruptive fissure east of the principal cone chain were nearly inactive, and at the fourth (easternmost) segment activity was very weak. At the latter the repetitive pattern of behavior consisted of a few seconds of quiet followed by loud hissing, culminating in a dull, hissing explosion that threw fragments of pasty lava 15 feet in the air. Along the main section of the active fissure lava fountains still played to heights of 50 to 75 feet.

Between $10^{\mathrm{h}}$ and $11^{\mathrm{h}}$ activity within Halemaumau was restricted largely to the northeast and southwest fountains. A prominent sinkhole was active from time to time near the northeast end of the 1952 cones. Many small avalanches were occurring on the crater walls. Striking the fluid lava of the lake, these caused 


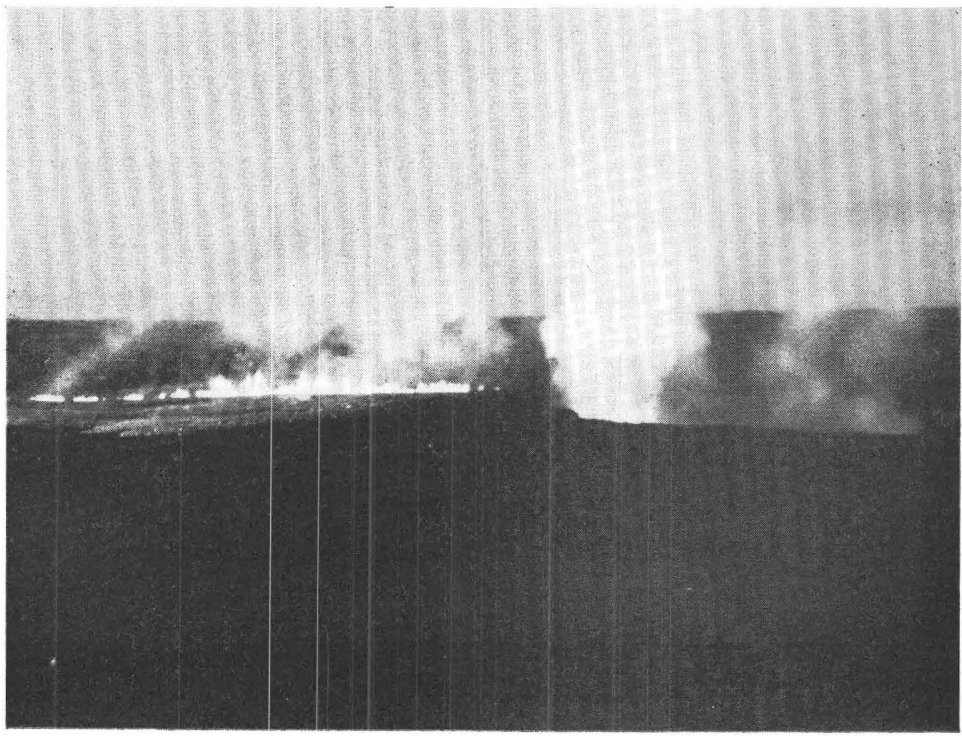

$A$, LAVA FOUNTAINS ALONG THE FISSURE NORTHEAST OF HALEMAUMAU AND LAVA FLOW SPREADING FROM THEM.

At the right, fume rises from the northeast edge of Halemaumau crater. Taken from Uwekahuna about $6^{\mathrm{h}}$ on May 31. Photograph by Ralph T. Kanemori, Modern Camera Center, Hilo.

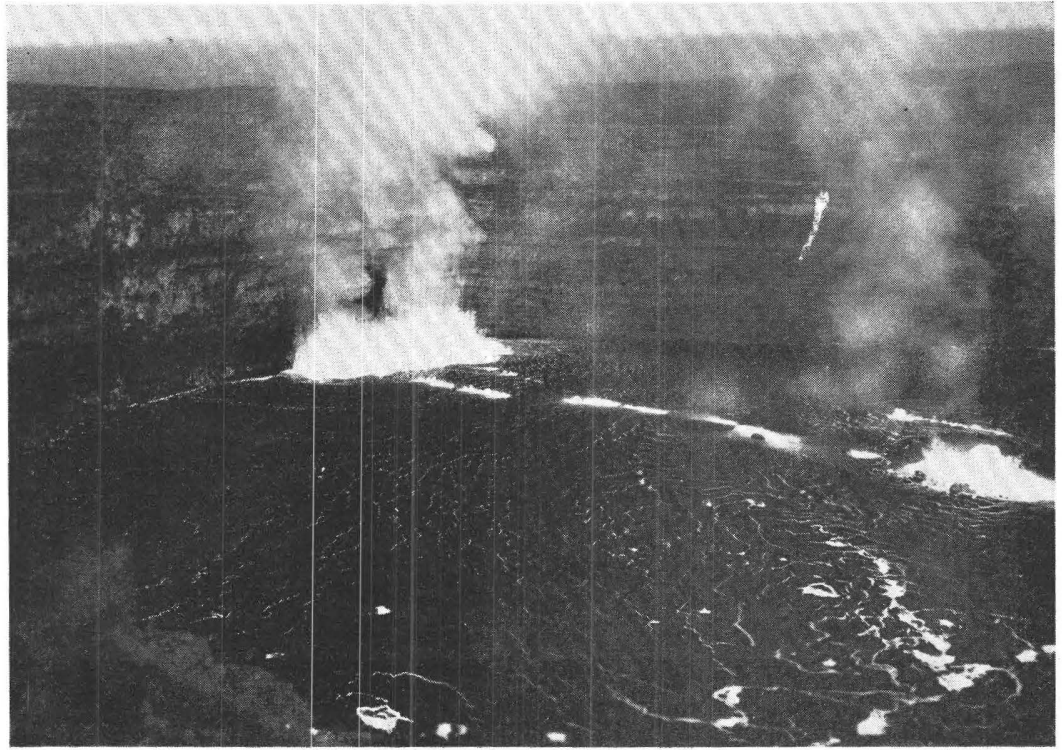

$B$, SOUTHWEST FOUNTAIN IN HALEMAUMAU.

To the right small fountains are playing along fissures that cross the 1952 cones. The bright lines on the crater floor are cracks in the dark lava crust, revealing the incandescent material beneath. Taken from the eastern rim about $6^{\mathrm{h}} 30^{\mathrm{m}}$ on May 31. Photograph by Ralph T. Kanemori, Modern Camera Center, Hilo. 


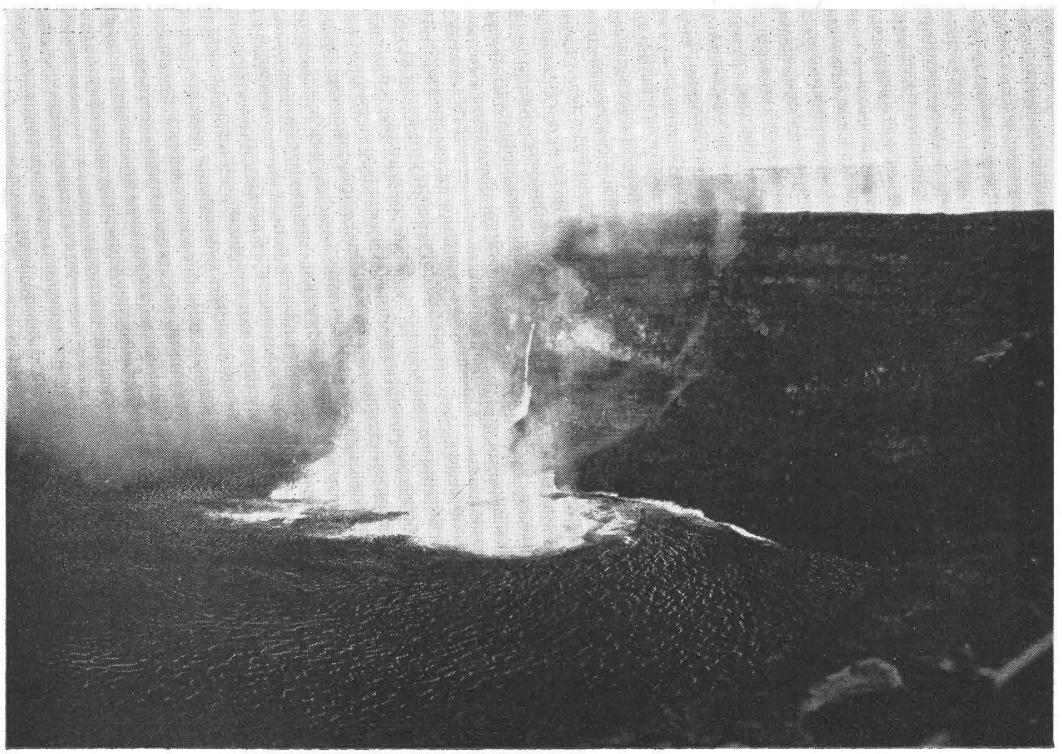

A, NORTHEAST FOUNTAIN IN HALEMAUMAU.

The cascade on the crater wall is just to the right of the fountain. The crater wall at the cascade is about 400 feet high. Taken from the eastern rim about $6^{\mathrm{h}} 30^{\mathrm{m}}$ on May 31. Photograph by Ralph T. Kanemori, Modern Camera Center, Hilo.

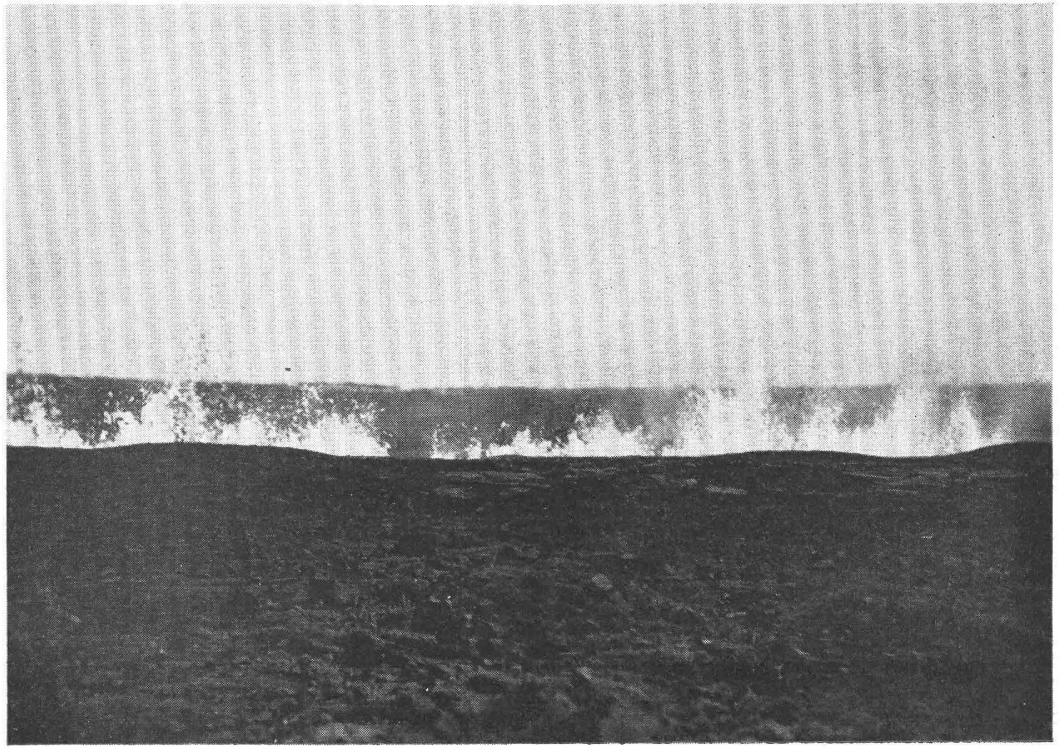

$B$, CHAIN OF LAVA FOUNTAINS.

Chain of lava fountains along the eruptive fissure on the floor of Kilauea caldera northeast of Halemaumau, seen from the southeast, about $6^{\mathrm{h}} 45^{\mathrm{m}}$ on May 31. The highest fountains are about 75 feet high. Photograph by Ralph T. Kanemori, Modern Camera Center, Hilo. 
violent splashing and sank quickly out of sight, to be followed for several minutes by a group of small, secondary fountains. The lava fountains northeast of Halemaumau continued to decrease in size, and by $11^{\mathrm{h}}$ were essentially inactive. By $13^{\mathrm{h}}$ the southwest fountain in Halemaumau had decreased to a height of only 50 feet, and the northeast fountain was throwing only sporadic showers of spatter to heights of less than 25 feet. A slump scarp was starting to form around the edge of the crater floor.

At $13^{\mathrm{h}} 30^{\mathrm{m}}$ fountains along the central part of the chain northeast of Halemaumau again became weakly active, throwing sporadic showers of incandescent ejecta to heights as great as 25 feet. This revival was brief. By $16^{\text {h }}$, the fountain activity outside Halemaumau was completely ended except for a few very weak flings and weak, whistling gas release. A little sluggish movement continued in the flow until evening, and glow was visible in the throats of the cones until the night of June 1.

By $15^{\mathrm{h}}$ the northeast fountain in Halemaumau was completely inactive, and the southwest fountain was throwing weak, sporadic bursts of ejetca to heights as much as 25 feet. Similar, but smaller fountains were active in the pit of the principal 1952 cones and just northeast of the 1952 cone group. The slump scarp around the edge of the floor continued to grow in height. By $16^{\mathrm{h}}$ it averaged about 25 feet high, and by the morning of June 1 its height was estimated at 40 feet.

During the evening of May 31 intermittent small showens of red-hot cinders were thrown from the throat of the 1952 cone, but the principal activity was at a vent about 500 feet northeast of the 1952 cones (pl. 1). At intervals of a few minutes noisy, semiexplosive bursts from that vent threw showers of incandescent ejecta to heights of about 100 feet. The ejecta falling and accumulating around the vent were building a small cone. The vent continued in similar activity until the afternoon of June 3. During daylight hours each blast was seen to be accompanied by a puff of bluish-white fume.

On the morning of June 1 two small flows were active near the northeast and east-northeast edges of the floor of Halemaumau, and some weak lava movement was visible from time to time near the southwest edge. This condition continued throughout the day. During the afternoon a tiny lava fountain, about 2 feet high, was visible at the head of the east-northeast flow. On June 2 the southwest and east-northeast flows had ceased, but the northeast flow continued active and was developing into a small lava lake. The lake was about 300 feet long and 100 feet wide, and was situated on the course of the eruptive fissure. Slow circu- 
lation in it, from east to west, was accompanied by some disintegration and foundering of the crust and small secondary fountains. No primary fountaining was visible. The lake became inactive at about $3^{\text {h }}$ on June 3. The last weak blasts from the semiexplosive central vent were observed at about $18^{\mathrm{h}}$ on June 3 . Thus, the duration of the eruption was roughly $31 / 2$ days.

Gradual shrinkage of the new lava fill in Halemaumau continued throughout the eruption and for several days thereafter. Old features, such as the 1952 cones and the prominent fault scarp running northeastward from them (Macdonald and Eaton, 1955, fig. 36), temporarily buried by the new lava, reappeared. The slump scarp around the edge of the crater floor eventually reached a height of about 45 feet.

\section{THE LAVA}

The lava that poured out onto the caldera floor northeast of Halemaumau is basalt containing only 1 to 2 per cent olivine. The olivine is present both as scattered phenocrysts as large as 2 millimeters across, and as microlites visible only under the microscope. The chemical composition of the lava is given in table $\mathbf{9}$.

The flow consists almost entirely of pahoehoe. Aa is present only locally in small patches. A particularly interesting feature is the development of typical clinkery aa in narrow bands, generally less than a foot wide, along the lines of principal shear near and parallel to the margins of lava streams. Part of the pahoehoe, especially that liberated late in the eruption, is dense, but much of it is very vesicular and shelly. Many toes near the edge of the flow are hollow, consisting of a thin crust 2 to 6 inches thick, covering a central opening as much as 2 feet in diameter. These toes appear to have been inflated by gas, like balloons. The edge of the flow is exceedingly irregular (fig. 12), and illustrates well the process of spreading of very fluid pahoehoe over a fairly flat but moderately irregular surface by the protrusion of innumerable lobate toes from the flow margin.

An upper layer of vesicular pahoehoe crust, generally 1 to 3 inches thick, apparently was essentially isolated from the underlying flow by a layer of gas bubbles. This crust behaved semiindependently from the flow beneath it, being dragged along by movement of the underlying liquid, folded and rolled into ropy forms, and locally fractured and tilted. At the edges of the flow this crust was in places thrust out as much as 3 or 4 feet over the adjacent rocks. 


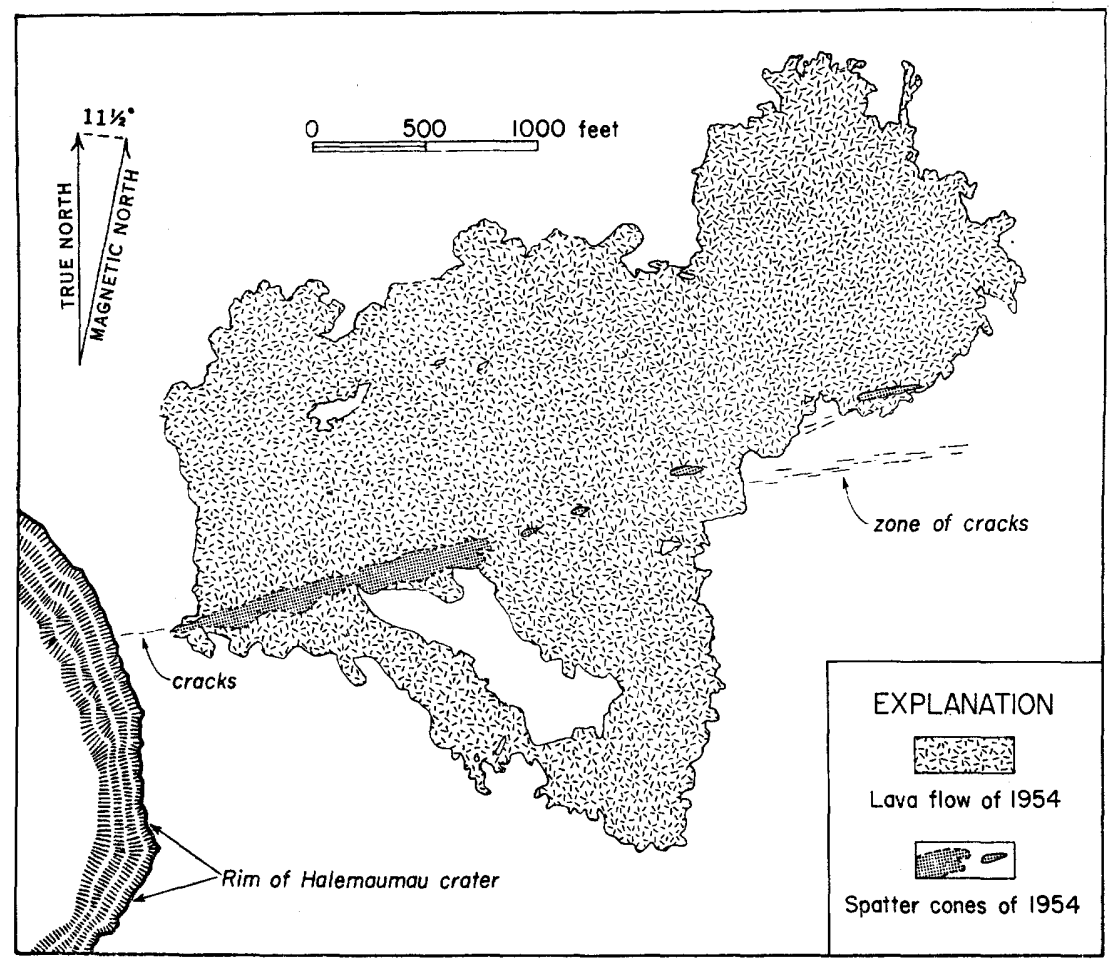

Figure 12.-Map of the 1954 lava flow on the floor of Kilauea caldera northeast of Halemaumau, showing the extreme irregularity of the edge of the flow.

The area covered by the flow northeast of Halemaumau is approximately 139 acres (fig. 12), and the volume of the flow is approximately 1.5 million cubic yards.

The rapid gush of liquid lava into Halemaumau during the first 8 hours of the eruption produced a fill averaging 63 feet in thickness, with a volume of about 15 million cubic yards. Most of the lava was extruded during the first 2 hours. About noon on May 31, a rapid sinking of the lava level began over the entire floor of Halemaumau, leaving a narrow band of congealed lava clinging to the crater walls. By the evening of May 31 the slump scarp thus formed around the edge of the floor was about 25 feet in height, and by the end of the eruption the scarp had increased to an average height of 32 feet. Thus the permanent fill of new lava in Halemaumau had an average thickness of 31 feet, and a volume of approximately 7 million cubic yards.

In Hawaii, shrinkage of ponded lavas on cooling and loss of gas commonly produces slump scarps, indicating a decrease of volume of as much as 20 per cent (Macdonald, 1954, p. 133-134). 
However, the decrease of volume of the new fill in Halemauman was about 52 per cent. This proportion appears far too great to have resulted from shrinkage due to loss of gas and cooling. Furthermore, the major part of the sinking of the new lava surface was too rapid to have resulted from those causes. Some of the new lava must have escaped downward, presumably drainin back into the fissures through which it had previously risen. The slower sinking of about 7 feet, after the evening of May 31, may have resulted partly from additional draining away of the liquid. but unquestionably also resulted in part from loss of gas anc' cooling.

TABLE 9.-Chemical and normative composition of the 1954 lava of Kilauea

[Analysts: major constituents, Lois Trumbull; minor constituents, Paul R. Barnett]

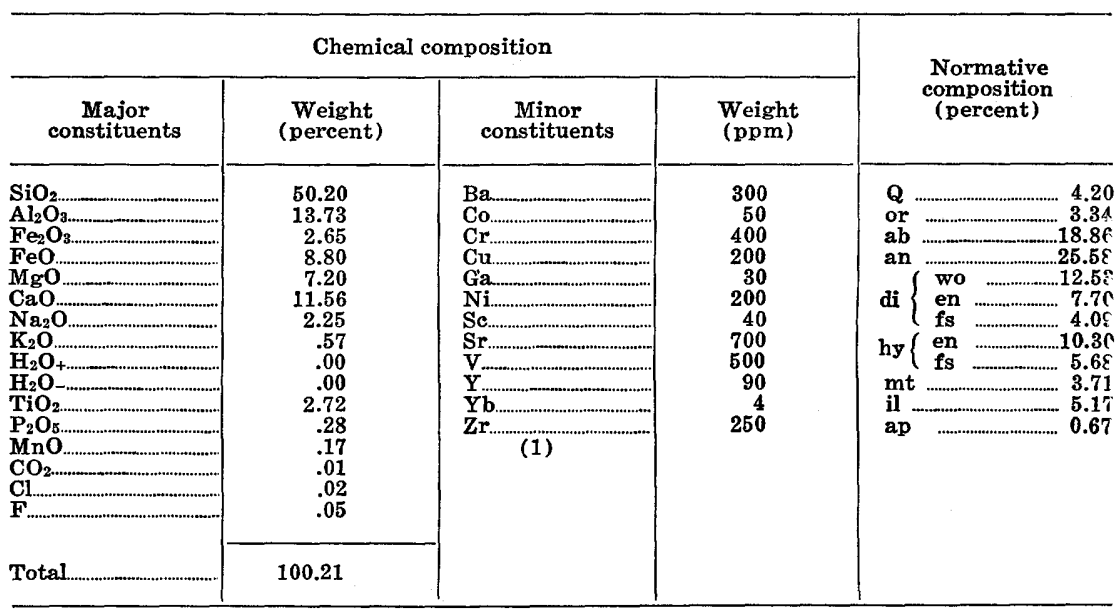

${ }^{1}$ Looked for but not found: Ag, As, Au, B, Be, Bi, Cd, Ge, In, La, Mo, Nb, Pb, Pt, Sb, Sn, Ta, Th, Tl, U, W, and $\mathrm{Zn}$.

\section{RADIOACTIVITY}

An attempt to determine the degree of radioactivity of the fume was only partly successful. An hour after the outbreak of the eruption Macdonald took a Geiger counter into the fume cloud at the southwest edge of Halemaumau. The fume was rising almost durectly upward, however, and only occasionally did moderately dense clouds blow momentarily over the ground at the rim. At no time was it possible to keep the counter tube in dense fume for long periods. Two counts for periods of only 1 minute each were obtained. A third count was made in fume rising from a crack several feet away from the crater rim. All counts were within the range of counts made on the caldera floor away from 
the crater rim on the morning of May 31, and those normally obtained in the Kilauea area at times of no surface volcanic activity. Thus, the counts obtained give no evidence of any concentration of radioactive material in the fume cloud, just as earlier counts have revealed no concentration in active flows or pumice ejected by the lava fountains (Macdonald and Orr, 1950, p. 24; Finch and Macdonald, 1953, p. 76).

\section{EARTHQUAKES ASSOCIATED WITH THE ERUPTION}

After the end of the last eruption of Kilauea in November 1952, seismic activity remained at a low level for about 5 months. On April 29, 1953, three moderate earthquakes originating on the southwest rift of Kilauea initiated a mild resurgence of seismic activity which continued throughout May, June, and July. August, September, and most of October were extremely quiet months at Kilauea.

A sequence of moderate to strong earthquakes on October 26-27 stemming from the east rift zone near the caldera was the first major seismic event of the volcano following the 1952 eruption. After another 3 weeks of quiet there began a series of frequent, small earthquakes originating at Kilauea caldera which continued until the end of the year.

The first 3 months of 1954 were very quiet. Coincident with the occurrence of two large earthquakes along the east rift zone of Kilauea between Pahoa and Kalapana on March 30, the series of frequent small to moderate quakes originating beneath Kilauea caldera began again. This series continued until the outbreak of the eruption on May 31.

The majority of the earthquakes during April and May were of shallow origin, not more than 3 to 5 miles deep, although between May 13 and 18 four quakes originated under the caldera region at depths of 15 to 25 miles. The majority of the quakes were small, only eight being felt in spite of the shallow focal depths. From March 30 through May 31 about 90 quakes were large enough to be identified as of Kilauean origin, while almost 900 quakes, too small to locate but apparently from Kilauea, were recorded at the Uwekahuna station. Like the larger members of the same group these small quakes appear to have been predominantly of shallow origin. Two characteristic types occurred. One had very sharp preliminary phases and an $S-P$ interval of between 0.2 and 1.5 seconds. The other had no identifiable phases, consisting only of a train of very irregular waves. Both types were recorded only by instruments around Kilauea caldera, and undoubtedly were of local origin. 
At $3^{\mathrm{h}} 26^{\mathrm{m}}$ on May 31 intermittent high-frequency spasmodic tremor began recording on the Sprengnether vertical seismograpl at Uwekahuna. About $3^{\mathrm{h}} 27^{\mathrm{m}}$ a series of small, sharp quakes begar recording at a rate of about one per minute, the records of the quakes being superimpased on the then continuous spasmodic. tremor. After $3^{\mathrm{n}} 42^{\mathrm{m}}$ the frequent quakes and continuous spasmodic. tremor became so large that the Sprengnether record was unreadable.

Between $3^{\mathrm{n}} 37^{\mathrm{m}}$ and the beginning of the harmonic tremor at: $4^{\mathrm{h}} 09^{\mathrm{m}}, 33$ quakes, several of which were felt, were recorded or seismographs around Kilauea caldera. The large quake at $3^{\mathrm{h}} \mathbf{4 3}^{\mathrm{m}}$, which originated at a shallow depth just east of Halemaumau, awakened people generally in the vicinity of the caldera.

\section{CONCLUSION}

The 1954 eruption of Kilauea is one of the shortest on record, being exceeded in brevity during recent years only by that of February, 1929, which lasted 2 days. The total final volume of lava left in Halemaumau and on the caldera floor was only about one-twelfth that extruded during 1952, but the rate of lava output during the first few hours of the eruption was very high, approximately equal to that during the corresponding part of the 1952 eruption.

The fissure eruption on the caldera floor east-northeast of Halemaumau appears to have been unique in the recent history. of Kilauea caldera. A search of the literature reveals no record of similar activity at least since the middle part of the 19th century. Before that, the records are too incomplete to constitute any reliable basis for comparison. The eruptive fissure extends almost directly toward the vents of the eruptions of 1832 and 1868 . Neither of those eruptions was on the caldera floor. The eruption of 1832 occurred on the Byron Ledge, spilling lava into the caldera and into Kilauea Iki Crater. In 1868 the eruption occurred on the wall of Kilauea Iki and sent no lava into the caldera proper. Both, however, were intimately associated with caldera activity, and the alignment of the 1954 fissure with the earlier vents suggests that this line marks an important zone of weakness across the caldera floor.

On or about May 4, 1877, an eruption occurred along a fissure at the southeast edge of Kilauea caldera. An entry by Thomas E. Cook in the Volcano House record book, under the date of May 21, 1877, states that the fissure from which the flow of lava issiled commenced at the base of the caldera wall and extended 
to within 20 or 30 feet of the top of the wall (Brigham, 1909, p. 132). Under the date of May 6, 1877, Sanford B. Dole states, also in the Volcano House record book, that the lava spouted from the fissure to heights of 50 to 150 feet (Brigham, 1909, p. 131). Activity appears to have lasted only a few hours, but lava covered several acres of the caldera floor. The eruption was accompanied by the draining of Halemaumau, leaving a fuming pit about 250 feet deep. The large size of the fountains and the location of the fissure indicate quite certainly that the eruption came from a primary, deep-seated vent, and was not merely an overflow from Halemaumau.

Eruption may have occurred in Keanakakoi Crater at about the same time. There appears, however, to be considerable doubt regarding the date of the lava that forms the floor of Keanakakoi (Stearns and Clark, 1930, p. 79).

The location of the eruptive fissure of 1877 is not known with certainty. H. A. Powers suggests (personal communication) that the small spatter cone at the southeast edge of Kilauea caldera just north of Keanakakoi (pl. 1) may have been formed at that time. The suggestion is highly plausible, but cannot be confirmed. Both the spatter cone and a 2-foot bed of cinder on the caldera wall south of it, 150 feet above the caldera floor, may have been formed during the 1877 eruption.

None of the lava outpourings on the caldera floor between 1877 and 1954 appear to have been from primary, deep-seated vents. In 1884 and 1885 lava flowed northeastward from Halemaumau to the caldera wall near Kilauea Iki, building a small cone, known as Little Beggar, near its point of emergence. Little Beggar was a well-known landmark on the floor of Kilauea caldera until it was buried by the 1954 eruption. It was a "rootless" driblet cone (Wentworth and Macdonald, 1953, p. 52) built by spatter from an opening in the roof of a lava tube. L. A. Thurston believed that overflows during 1894 destroyed the original Little Beggar cone, and built another in its place (Stearns and Clark, 1930 , p. 79). However, comparison of a photograph of Little Beggar in 1889 published by Brigham (1909, p. 157), with others taken during recent years indicate that it probably was the same cone. If there were two Little Beggars they were very closely similar in form and identical in origin. It appears probable that the 1884-85 flow was simply a drainage from the Halemaumau lake, through fissures in the edge of the broad, shield-shaped Halemaumau cone. Certainly no strong lava fountaining occurred at the 1884 vent. The 1894 lava flooding in the same general area undoubtedly also was merely an overflow from the Halemaumau lake. 
The line shown by Stearns and Clark (1930, pl. 1) and Stearrs and Macdonald (1946, pl. 1) as a source fissure is a fissure in which lava rose probably during the activity of $1884-85$. The new lava can be seen along much of the fissure, a few feet beneath the surface of the surrounding terrain. However, pressure seems to have been inadequate to raise the lava quite to the surface. No new flows appear to have issued from the fissure.

The outpourings of 1918-19 also were merely overflows from the Halemaumau lake, even though the latter sent a big strear of lava all the way to the northern wall of the caldera. The 1921. flow, over the southern part of the caldera, issued from cracks southwest of Halemaumau formed at the time of the 1919-20 outbreak in the Kau Desert. Two prominent conelets were formed at the points of issue of the lava. However, the fountains at thos: vents were low and gas-poor, and photographs of the conelet: show them to have been driblet cones. Almost surely, the eruption of 1921, like those of $1884,1894,1918$, and 1919, was merely an overflow from the Halemaumau lake.

Persons familiar with the behavior of Kilauea previous to the great collapse in 1924 have remarked on the distinct change in character of its behavior during the 1952 and 1954 eruptions (Isabel P. Jaggar, personal communication). Unquestionably, the last two eruptions have resembled much more closely the eruptive habit of Mauna Loa than that of Kilauea during the 19th century and early part of the 20th. Probably, however, the change does not represent any fundamental alteration in the eruptive habit, of Kilauea, but rather merely reflects the absence of an open vent, between eruptions (or lava overflows). The open conduit, markec by the presence of the active lava lake most of the time from 1823 to 1924, prevented the accumulation of any large "head" of gas on the magma column, and consequently the formation of large gas-rich fountains such as have characterized the activity of Mauna Loa and the 1952 and 1954 eruptions of Kilauea. There is no good reason to believe, however, that the "permanent" lava lake and open conduit have been characteristic of Kilauea volcano throughout its period of growth. Its geologic structure and the formations at prehistoric vents indicate, on the contrary, that throughout most of its growth it has closely resembled Mauna Laa. The century of nearly constant lava-lake activity, on which most of our knowledge of Kilauea is based, may well have been an unusual period in the long-term history of the volcano. 


\section{PUBLICATIONS OF THE HAW AIIAN VOLCANO OBSERVATORY}

In addition to the annual reports of the observatory, published as bulletins of the Geological Survey, reports by staff members on volcanic conditions and features in Hawaii and elsewhere appear in other publications. A report on earthquake and ground tilting, and a summary of volcanic conditions appear quarterly in the Volcano Letter, published by the University of Hawaii. Technical papers appear as lead articles in the Volcano Letter, and in other technical journals. The latter form a series known as "Contributions" of the Hawaiian Volcano Observatory. Papers in these two series published during 1954 are listed below.

\section{VOLCANO LETTER}

Macdonald, G. A., and Alcaraz, A., 1954, Philippine volcanoes during 1953 and early 1954: no. 523, p. 1-5.

Macdonald, G. A., and Eaton, J. P., 1954, The eruption of Kilauea volcano in May, 1954: no. 524, p. 1-9.

Eaton, J. P., 1954, A method for recording radio time signals on seismograms: no. 525, p. 3-5.

Macdonald, G. A., Davis, D. A., and Cox, D. C., 1954, Kauai, an ancient Hawaiian volcano: no. 526, p. 1-3.

\section{CONTRIBUTIONS}

Macdonald, G. A., 1954, Philippine volcanoes: Hawaiian Acad. Sci., Proc. for $1953-54$, p. 16.

1954, Activity of Hawaiian volcanoes during the years 1940-50: Bull. volcanologique, $2 \mathrm{~d}$ ser., v. 15, p. 119-179.

Macdonald, G. A., and Wentworth, C. K., 1954, The tsunami of November 4, 1952, on the island of Hawaii: Seismol. Soc. America Bull., v. 44, p. 463-469.

Wentworth, C. K., 1954, The physical behavior of basaltic lava flows: Jour. Geology, v. 62 , p. $425-438$.

Macdonald, G. A., 1954, Igneous rocks (of Sylvania guyot) ; in Emery, K.O., and others Geology of Bikini and nearby atolls; part 1 Geology: U. S. Geol. Survey, Prof. Paper 260-A, p. 120-124.

\section{IITERATURE CITED}

Benioff, H., 1951, Earthquakes and rock creep-part 1: Creep characteristics of rocks and the origin of aftershocks: Seismol. Soc. America Bull., v. 41, p. 31-62.

Brigham, W. T., 1909, The volcanoes of Kilauea and Mauna Loa on the island of Hawaii: B. P. Bishop Mus. Mem., v. 2, no. 4, Honolulu, 222 p. Finch, R. H., and Macdonald, G. A., 1951, Report of the Hawaiian Volcano Observatory for 1948 and 1949: U. S. Geol. Survey Bull. 974-D, p. 103-133. 
1953, Hawaiian volcanoes during 1950; U. S. Geol. Survey Bull. 996-B, p. 27-89.

Gutenberg, B., and Richter, C. F., 1942, Earthquake magnitude, intensity, energy, and acceleration: Seismol. Soc. America Bull., v. 32, p. 163-191.

Macdonald, G. A., 1944, Solfataric alteration of rocks at Kilauea volcano: Am. Jour. Sci., v. 242, p. 496-505.

1954, Activity of Hawaiian volcanoes during the years 1940-50; Bull. volcanologique, ser. 2, v. 15, p. 120-179.

- 1955, Hawaiian volcanoes during 1952: U. S. Geol. Survey Bull. 1021-B, p. 15-107.

Macdonald, G. A., and Eaton, J. P., 1955, Hawaiian volcanoes during 1953: U. S. Geol. Survey Bull. 1021-D, p. 127-166.

Macdonald, G. A. and Orr, J. B., 1950, The 1949 summit eruption of Mauna Loa: U. S. Geol. Survey Bull. 974-A, p. 1-33.

Macdonald, G. A., and Wentworth, C. K., 1954, Hawaiian volcanoes during 1951: U. S. Geol. Survey Bull. 996-D, p. 141-216.

Stearns, H. T., and Clark, W. O., 1930, Geology and water resources of the Kau District, Hawaii: U. S. Geol. Survey Water-Supply Paper 616, $194 \mathrm{p}$.

Stearns, H. T., and Macdonald, G. A., 1946, Geology and ground-water resources of the island of Hawaii: Hawaii Div. Hydrography, Bull. 9, $363 \mathrm{p}$.

Wentworth, C. K., and Macdonald, G. A., 1953, Structures and forms of basaltic rocks in Hawaii: U. S. Geol. Survey Bull. 994, 98 p.

Wilkes, Charles, 1845, Narrative of United States Exploring Expedition during the years 1838-1842, v. 4, 539 p., Lea and Blanchard, Philadelphia. 


\section{N D E X}

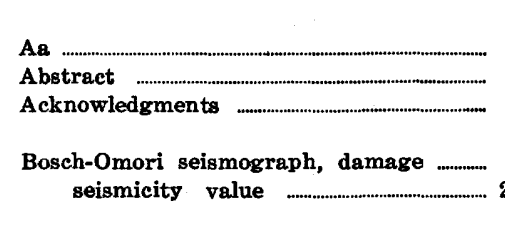

Crack measurements, along east rift zone of Kilauea . 38,39 near rim of Halemaumau on floor of Kilauea caldera. stations destroyed

38,39 38,39 38,40

Damage, earthquake of March 30 $52-54$ Declining phase of eruption 60-62

Earthquakes, associated with eruption..... distant origin

65,66

local origin

number recorded during 1954 per week of March 30 seismicity

East rift zone of Kilauea caldera, crack-measuring stations.....

Epicenters, distant earthquakes local earthquakes

31,82 27-30 52-55 26 38,39 31,32 27-30

Fumarole gases

Gas, from eruption $56,58-64$ radioactivity

Geomagnetism, differences in vertical intensity

Gutenberg - Richter magnitude - energy formula n rainfall record

Halemaumau crater, crack measurements

Hamakua, earthquakes felt in

Hawaiian Volcano Observatory, number of earthquakes recorded monthly 42-44

Hilina fault, earthquakes originating on Hilo, earthquakes felt in. $42,43,44,46$,

$48,54,55$

History of volcanic activity in Kilauea.... 66-68 Hualalai volcano, earthquakes originating under
(1)

Imamura seismograph

Jaggar vertical seismograph, location..... 22

Kalapana, earthquakes felt in ....................... 43

Kamuela, earthquakes felt in ......................... 48, 49

Kamuela seismograph station ..................... $\quad 19$

Kaoiki fault, earthquakes originating on 48

Kealakekua fault, earthquakes originating on .................................45, 46, 47

Kilauea, crack measurements along east rift zone ........................................ 38,39

deposition and alteration on the floor of the caldera................ 49,50 earthquakes originating under.......... 42, 43, $45-49,55,65$ eruption of ...................................................4 45, 55-62 Kilauea caldera, tilting of the ground...... 44, 46, $47,48,55$

Kilauea caldera region, weekly and cumulative strain-release indices

Kohala, earthquakes felt in ...........................43, 49

Kona, earthquakes felt in .......................... 42, 48,

$45,46,47,48,54$

Lava, area covered ............................................ 63

composition of ................................... 62, 64

duration of flow ................................ 62

flow of May 31 .......................................... 56-62

fountains, description ............................... 57-62

level in Halemaumau ............................... 63

shrinkage ..............................................................

volume of flow ....................................... 63

Loucks-Omori seismograph ................................. 18

56-62 Mauna Kea, earthquakes felt on .................. 45, 54

41, 42 Manua Loa, earthquakes originating under

$45,47,49$

Mauna Loa, truck trail, rainfall record 41,42

Mauna Loa seismograph station, rainfall record 41,42

Naalehu seismograph station ........................ 19

Olivine ...............................................................................

Pahoa seismograph station .............................. 19 earthquakes recorded at ..............................46, 46 


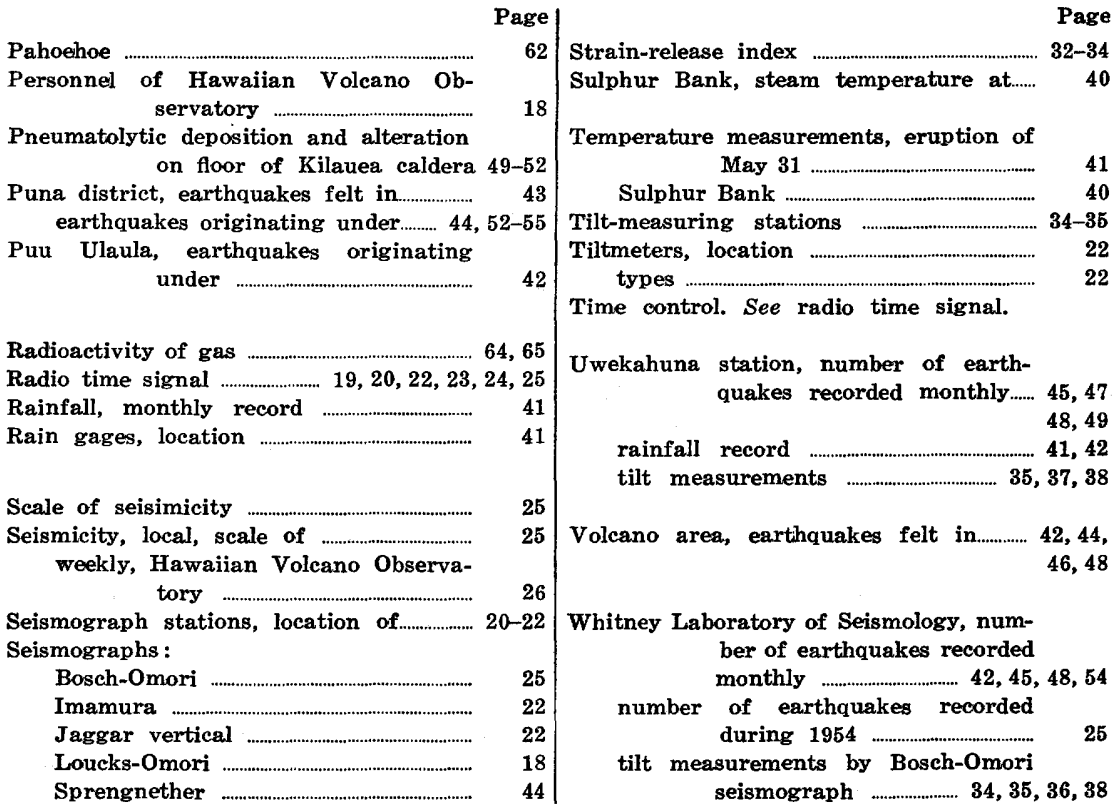

it U. S. GOVERNMENT PRINTING OFFICE: 1957-426708 